\title{
Effects of perinatal meditation on pregnant Chinese women in Hong Kong: A randomized controlled trial
}

\author{
Ka Po Chan * \\ The Buddhist Institute of Enlightenment (HK) Ltd, Hong Kong, China
}

Received: September 8, 2014

Accepted: October 10, $2014 \quad$ Online Published: October 19, 2014

DOI: $10.5430 /$ jnep.v5n1p1

URL: http://dx.doi.org/10.5430/jnep.v5n1p1

\begin{abstract}
Objective: To assess the effects of Perinatal Meditation on pregnant Chinese women in Hong Kong.

Design: A prospective longitudinal randomized control quantitative study. Data were collected using the Prenatal Distress Questionnaire, Prenatal Coping Inventory, Edinburgh Postnatal Depression Scale, Body-Mind-Spirit Well-Being Inventory (BMSWBI) and salivary cortisol. Data were collected during first visit, 36 th weeks pregnant, $5^{\text {th }}$ weeks and $5^{\text {th }}$ months after delivery.

Settings: Perinatal meditation program (Eastern Based Meditative Intervention, EBMI) for pregnant Chinese women in Hong Kong who were attending the hospital clinic for routine perinatal care.

Participants: 64 pregnant Chinese women were recruited for intervention and 59 were for control. 36 cases were classified as Frequent Practice (FP) in intervention group.

Results: Quantitative results showed statistically significant increase in positive appraisal $(p<.05)$ at 36th weeks, difference in evening salivary cortisol $(p<.05)$ and decreased in physical distress $(p<.05)$ at $5^{\text {th }}$ weeks postpartum in the Frequent Practice (FP) group.

Conclusions: Frequency of practice of meditation is directly related to its effects. Perinatal meditation can help pregnant women to reduce perinatal stress through its effect on coping mechanism and improves physical discomfort in postnatal period which are risk factors for maternal health, fetal health and child health. Perinatal meditation can be added into present perinatal counselling and perinatal program to promote maternal health, child health and family health.
\end{abstract}

Key Words: Coping, Meditation, Physical distress, Pregnancy stress, Maternal health, Fetal health, Child health, Prenatal care, Postnatal care, Program evaluation

\section{Introduction}

Transition to motherhood is a time of psychological stress together with physical discomforts that poses critical adaptation challenges. ${ }^{[1,2]}$ Estimates of the prevalence of ante- natal psychological distress in pregnant women in industrialized countries are between $8 \%$ and 24\%. ${ }^{[3-5]}$ Woods et al. ${ }^{[6]}$ reported that antenatal psychosocial stress is common, and high levels are associated with maternal factors

\footnotetext{
* Correspondence: Dr. Ka Po Chan; Email: drchankapo@gmail.com; Address: RM 1202, Onward building, 528 Nathan road, Kowloon, Hong Kong, China 
known to contribute to poor pregnancy outcomes. Recent information has found that even minor aliments during pregnancy may have psychosocial factors. ${ }^{[7-9]}$ Perinatal stress is well known as an independent risk factor for adverse pregnancy outcomes and affects maternal health, infant health and child health. ${ }^{[1,6,10-16]}$

Stress in pregnant women, coupled with the use of less effective coping strategies, has been associated with poorer maternal well-being, including depression and anxiety. ${ }^{[17-20]}$ Pregnant women with high stress and anxiety levels are at increased risk for spontaneous abortion and asymmetric growth retardation. ${ }^{[21-24]}$ Pregnancy-specific stress contributed directly to preterm delivery. ${ }^{[11,21,23,25-29]}$ A decline in stress response during pregnancy may help to protect mother and foetus from adverse influences associated with preterm birth. ${ }^{[30]}$

During exposure to a stressor, the whole system of stress regulation, consisting of the hypothalamus pituitary adrenal cortex system (HPA axis) and the sympathetic nervous system-adrenal medulla system, is activated. Various hormones, including $\mathrm{CRH}$, adrenocorticotropin-releasing hormone (ACTH), cortisol, and noradrenaline, are released in large quantities into the systemic circulation. ${ }^{[14,31-33]}$ Weinstock $^{[33]}$ reviewed that excess circulating maternal stress hormones alter the programming of foetal neurons, and together with genetic factors, the postnatal environment and quality of maternal attention, determine the behaviour of the offspring. Christian ${ }^{[1]}$ found that stress-induced immune dysregulation during pregnancy has unique implications for both maternal and fetal health. Prenatal stress has been linked to adverse effects in her child. ${ }^{[10]}$ O'Donnell et al. ${ }^{[34]}$ found that prenatal maternal mood is associated with altered diurnal cortisol in adolescence. The adverse effects appear to extend into the adolescence and adulthood of the offspring of prenatally stressed mothers, leading to altered neuro-behavioural development, childhood and adolescent mental and physical health problems. ${ }^{[35-54]}$ Maternal life stress events in pregnancy linked to children's school achievement even at age 10 years. ${ }^{[50,55]}$ Multiple clinical studies have, in fact, repeatedly confirmed that prenatal maternal stress are pivotal in shaping behavioural and cognitive impairments in off-spring. ${ }^{[56]}$

Women's physical and emotional self-rated health is affected negatively by pregnancy during first year of motherhood. ${ }^{[58]}$ The early postal period is considered a vulnerable time for the mother and the family, as they are confronted with the demands of caring for their infant and the physical, emotional and social changes. ${ }^{[59,60]}$ Postnatal mental disorders are associated with underweight, stunting and impaired social and cognitive development in children. ${ }^{[61,62]}$ Maternal depression during perinatal period and early childhood may lead to poor physical health in early childhood and affects young adults' social functioning and mental health. ${ }^{[63]}$ Maternal anxiety levels have relationship with postnatal fa- tigue. ${ }^{[64]}$ Ongoing postnatal fatigue has been associated with development of maternal depression, early cessation of breast feeding and lower infant developmental performance. ${ }^{[65-67]}$

The major advance in caring for pregnant women in past decades has been the development of antenatal and postnatal care systems but only some of them have psychosocial intervention for women empowerment. ${ }^{[59,68-85]}$ Meditation is proven to be an excellent adjunctive treatment for many diseases. ${ }^{[86-94]}$ It is worthwhile to have more information about the effects of meditative intervention on perinatal women's health. ${ }^{[95-103]}$ The main objective of this study is to examine the effects of perinatal meditation on pregnant Chinese women in Hong Kong. The author has developed an Eastern based meditative intervention (EBMI) for pregnant Chinese women in Hong Kong. ${ }^{[104]}$ The theoretical background of EBMI bases on the integration of mindfulness practice, the Four Immeasurables, cognitive therapies and Western psychology and psychotherapy. The characteristic of EBMI is that through meditative practice, we can have right awareness, change our mental process, train and transform our mind. EBMI improves the capacity for recognizing and solving problems. ${ }^{[105]}$ EBMI included strategies that aimed at increasing awareness of the effect of stress, coping with stressful situation, ${ }^{[99]}$ increase positive thinking and pleasant activities, improving self-esteem, increasing self-care and learning skills to increase social support, and identifying and exploring unrealistic expectations about pregnancy and motherhood. EBMI for antenatal classes works in line with the theory of salutogenic theory sense of coherence (SOC) ${ }^{[106-109]}$ which enhances the comprehensibility, manageability and meaningfulness of life of pregnant women. EBMI focused on training participants in restructuring skills and techniques for identifying and modifying irrational thoughts that may affect their mental health in the perinatal period. Participants were asked to focus on cultivation of positive emotion and aware of their strengths to overcome negative thoughts through meditative practice. The programme emphasizes on self-discipline and self-directed coping. ${ }^{[110]}$ The effects of the EBMI are consistent with Rosenbaum's view ${ }^{[111]}$ of the beneficial effects of learned resourcefulness on individual's psychological well-being under stressful encounters. The acceptability of EBMI based on the chance of practice on daily basis and incorporates into the daily activities of the participants. ${ }^{[12,113]}$ EBMI is trans-cultural and suitable for individuals of diverse faiths. ${ }^{[114]}$ The intervention was delivered in a group format. Contents of EBMI were listed in Table 1. Figure 1 summarized the benefits of EBMI for pregnant Chinese women.

\section{Method}

Participants were pregnant Chinese women who attended private obstetrician clinics and antenatal clinics of Queen 
Elizabeth Hospital in Hong Kong (2007-2009). The present research had chosen one of the most common types of non-probability sample called convenience sample method. Chosen from a particular date onwards; any pregnant women who attended the clinics with maturity around twelve week to 28th week were invited to take part in the research. Sample size was based on statistical calculation.
Participants were randomized placed into two groups, the intervention group and the control group. The intervention groups had six sessions which comprised of the elements of EBMI conducted by the researcher. The control group had only one session and was the introductory lecture for the intervention group without the elements of intervention.

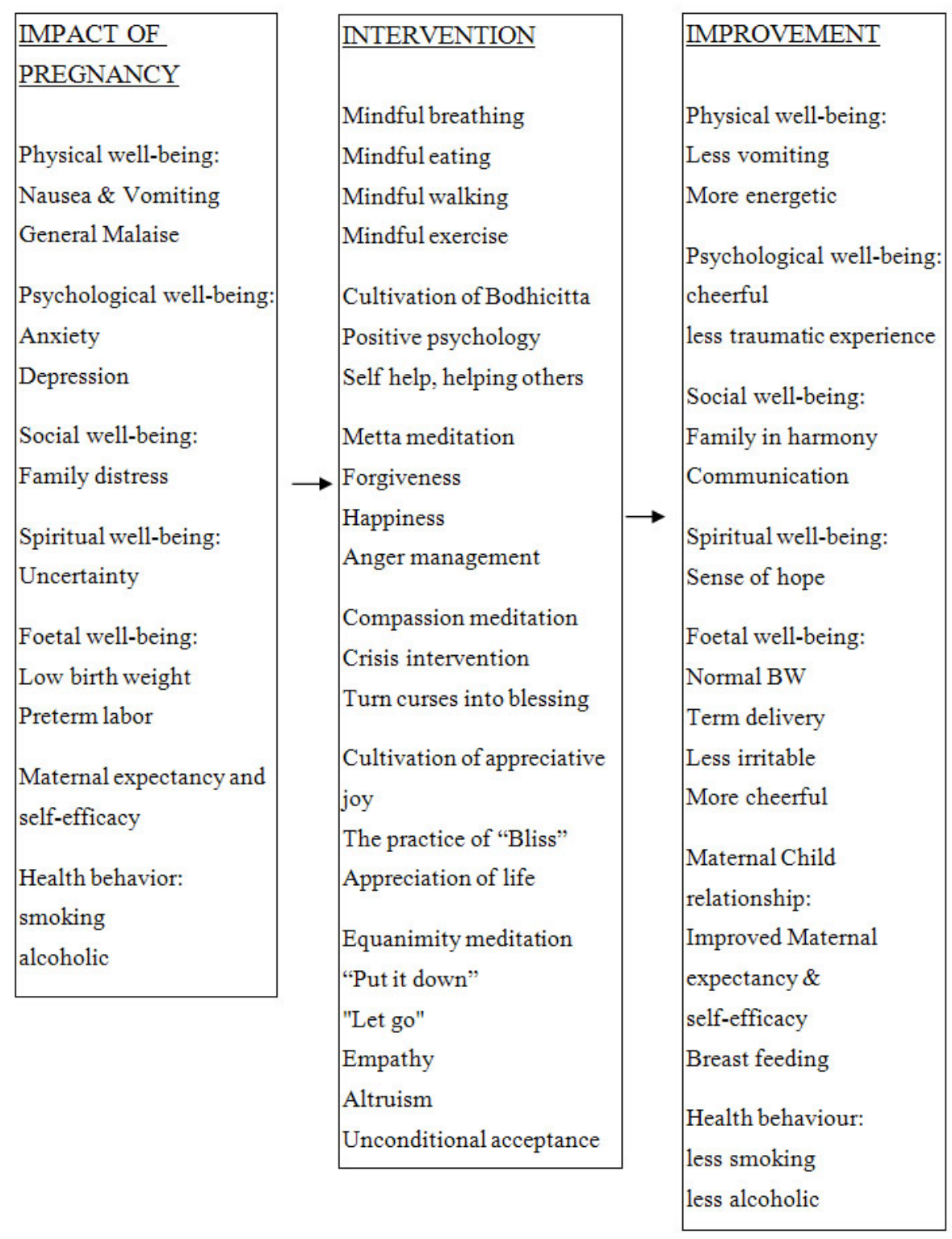

Figure 1: Intended benefits of EBMI for pregnant Chinese women.

All participants that took part in the study had a detailed history taking during the first visit. The demographic and obstetric questionnaires were developed by the researcher in lay-Persian to gather information on the participants' age, gestational age, lifestyle status, financial condition, employment, educational situation, obstetric history, medical history and spiritual history. The participants filled in their first questionnaire chosen, the Prenatal Distress Questionnaire, ${ }^{[115]}$ the Prenatal Coping Inventory, ${ }^{[115]}$ Edinburgh Postnatal Depression Scale (EPDS) and the BodyMind-Spirit Well-Being Inventory (BMSWBI) ${ }^{[116]}$ during their first visit. The pregnant women were instructed to check their first salivary cortisol levels. They were asked to collect saliva samples at wake-up and before bedtime on 
the same day. Second salivary cortisol level and second questionnaire study were taken around 36th week. Third questionnaire study with Edinburgh Postnatal Depression Scale (EPDS) and the Body-Mind-Spirit Well-Being Inventory (BMSWBI) were taken around fifth week after delivery. Fourth questionnaire study with Body-Mind-Spirit Well-Being Inventory (BMSWBI) was taken around fifth month after delivery. All participants had the salivary cortisol samples taken at fifth week and fifth month after delivery.

Table 1: Contents of EBMI.

\begin{tabular}{l}
\hline Contents of EBMI \\
\hline Mindful eating \\
Mindful walking \\
Mindful prenatal and postnatal exercises \\
Daily practice of 'self-help, helping others' \\
Crisis intervention: turn curse into blessing \\
Daily practice of 'bliss' \\
Let go \\
Three minutes-breathing practice \\
Body scan \\
Mindful breathing \\
Four Immeasurables Meditation
\end{tabular}

The Prenatal Distress Questionnaire was chosen as one of the instruments to be used in this study. Descriptive studies indicate that by mid- pregnancy, women often become concerned about medical problems, physical symptoms, parenting, relationships, bodily changes, labour and delivery and the health of the baby. Based on the relevant literatures, a 12-item instrument pertaining to these concerns was created. ${ }^{[115]}$ The Prenatal Coping Inventory was chosen as another instrument for this study which aims to assess worries and concerns related to pregnancy. ${ }^{[117]}$ Standard versions of coping instruments ${ }^{[118,119]}$ cannot fully capture the situational-specific ways in which women may manage the strains and challenges of being pregnant and contain some items inappropriate for this population. The Edinburgh Postnatal Depression Scale (EPDS) was chosen in present study to screen out suspected cases for referral and treatment. EPDS has been used in antenatal to detect current illness although further work is required on the effects on its sensitivity and specificity. ${ }^{[120-122]}$ Total scale scores ranged from 0 to 30 , with scores exceeding twelve indicative of depression. The advantage of the EPDS is that it removes items related to physical symptoms of depression (e.g., appetite) that may be affected by the postpartum re- covery period itself rather than mood. Chan, et al. ${ }^{[123]}$ had conducted a qualitative study of the experiences of a group of Hong Kong Chinese women suffered from postnatal depression. This study confirms the value of using Edinburgh Postnatal Depression Scale (EPDS) as a screening tool for PND in Chinese. The Body-Mind-Spirit Well-Being Inventory (BMSWBI) ${ }^{[116]}$ developed by the Centre on Behavioural Health, University of Hong Kong was chosen as an instrument to assess general well-being. This scale contains four subscales: Symptoms of distress, Emotion, Social Functioning and Spirituality. This inventory was used in this study because of its suitability to Chinese culture and the idea of holistic health.

Various studies use maternal salivary cortisol as measurements of mental health. ${ }^{[31,32,124,125]}$ In present study, salivary samples were collected at wake-up and bedtime (30 min before going to bed) into pre-labelled Salivette tubes (Starstedt, Ag \& Co., Nümbrecht, Germany) and immediately frozen until assay. The salivary cortisol level was determined by using an enzyme-linked immunoabsorbent assay kit (EIA) in the Centre on Behaviour Health at the University of Hong Kong (Salimetrics, Inc., State College, PA, USA). The assay sensitivity for the kit was $0.007 \mathrm{~g} / \mathrm{dl}$. Intraassay and inter-assay coefficients of variation were $3 \%$ and $10 \%$, respectively.

Data collected from questionnaires went through the process of coding. Descriptive statistics were used to summarize data. Chi-square analysis and independent $t$ - tests were used to detect any significant differences between two groups on the baseline variables.

\section{Ethical approval}

The author declared that the research is the original work of the author. The research was approved by the Research Ethics Committee (Kowloon Central/ Kowloon East), Hospital Authority of Hong Kong (2007).

\section{Results}

There are total 179 cases recruited for both intervention and control groups. Data collection was completed in October 2009. 64 cases have valid data from intervention group while 59 cases with valid data from control groups (see Table 2). Statistical analysis was done along different time zones (see Table 3). With data available about the frequency of practice of EBMI in intervention group at T2 and T3, present study divides this group into two subgroups, those with Frequent Practice (FP) and not Frequent Practice (Not FP). The criterion was based on a five point score $(0,1,2,3,4)$ on five items of EBMI. The five items included self-help, helping others, turn curse into blessing, bliss, let go and mindful breathing. They were chosen because they are frequently practised by the participants. Those who scored more than ten were labelled as Frequent Practice (FP) (n = 
36) and those who scored equal to or less than ten were not Frequent Practice (Not FP) $(n=22)$ (see Table 4). Statistical analysis was done along different time zones for intervention and control groups, between FP group and control group and FP and Not FP group.

The demographic characteristics of the intervention group and control groups reveal no significant difference (see Table 5). The demographic characteristics of the intervention group and control groups reveals no significant difference in age, age of husband, education level, and financial situation, habit of doing exercise before pregnancy, personal habit and past health. $79.7 \%$ of participants in the intervention group and $71.4 \%$ in the control group are primigravida. It is interesting to note that most of the multiparous patients attend the intervention group are with past history of vaginal deliveries $(93.5 \%)$ which is statistical significant $(p<.05)$ in compare with those in the control group (80.4\%). All participants have no past history of obstetric complications.

The comparison of Pregnancy Distress Score at T1 and T2 between intervention group and control group, FP and control group and FP and Not FP group are not of statistical significance. Results of comparison of Prenatal Coping Inventory at $\mathrm{T} 1$ and $\mathrm{T} 2$ between intervention group, FP group and control group, FP group and Not FP group were shown in Table 6. Analysis of Prenatal Coping Inventory revealed that there are differences in seeking social support and self-care between intervention and control group and FP and Control group at $\mathrm{T} 1$ and $\mathrm{T} 2$. The score on positive appraisal is increased for FP group as compare to Control at T2 $(p<.05)$. The increase in positive appraisal between FP and Not FP at T2 is also of statistical significant $(p<.05)$. Results of EPDS for intervention and control group, FP and control group and FP and Not FP group at T1, T2 and T3 are shown in Table 7. The differences are not of statistical significant. The differences between four sub-scores and the total score of BMSWI between intervention group and control group at T1, T2, T3 and T4 are not of statistical significant. The score on physical distress between FP and control group at T3 is of statistical significant $(p<.05)$ (see Table 8 ). Some patients did not return the questionnaires or fill in the questions asked and lead to lot of missing data. Results of maternal salivary cortisol level at different Time Zone of intervention and control group, FP and control group were shown in Table 9. The difference in evening salivary cortisol at T3 between FP and control group is of statistical significant $(p<.05)$. Some patients did not return the salivary samples and lead to lot of missing data.

\section{Discussion}

Meditative practices have received much attention and have stimulated lots of scientific studies. ${ }^{[126-150,152-156]}$ Med- itation may lead to improvements in attention stability, sustained response inhibition, information processing efficiency, alerting, emotional expression and the increase of self-maturity. ${ }^{[86,157-159]}$ Evidence suggests that meditation as an intervention has a strong relationship to positive health outcomes, overall well-being and adjunctive treatment for diseases. ${ }^{[86,87,92,94,159-187]}$ Dasari \& Kodenchery ${ }^{[25]}$ found that transcendental meditation and sequential muscle relaxation along with tocolytics were found to be more effective in inhibiting preterm labour and prolonging pregnancy than tocolysis alone. Beddoe et al. ${ }^{[188]}$ examined the effect of mindful yoga on pregnant women and found that there is decreased total number of awakenings at night and sleep efficiency in second trimester is improved. Duncan \& Bardacke $^{[189]}$ did a pilot study of $(n=27)$ pregnant women participating in Mindfulness-Based Childbirth and Parenting (MBCP) program during their third trimester of pregnancy. MBCP is designed to promote family health and well-being through the practice of mindfulness during pregnancy, childbirth and early parenting.

Table 2: Validity of data from participants.

\begin{tabular}{|c|c|c|c|c|c|}
\hline & & Frequency & Percent & $\begin{array}{l}\text { Valid } \\
\text { percent }\end{array}$ & $\begin{array}{l}\text { Cumulative } \\
\text { t percent }\end{array}$ \\
\hline \multirow{4}{*}{ Valid } & Control group & 56 & 31.3 & 31.3 & 31.3 \\
\hline & Intervention group & 64 & 35.8 & 35.8 & 67.0 \\
\hline & $\begin{array}{l}\text { Excluded (missing } \\
\text { data) }\end{array}$ & 59 & 33.0 & 33.0 & 100.0 \\
\hline & Total & 179 & 100.0 & 100.0 & \\
\hline
\end{tabular}

Table 3: Validity of data from Time Zone for Data analysis

\begin{tabular}{ll}
\multicolumn{2}{c}{ Time Zone for Data analysis } \\
\hline T1 & Baseline \\
T2 & Around $36^{\text {th }}$ week gestation \\
T3 & Around $5^{\text {th }}$ week postpartum \\
T4 & Around $5^{\text {th }}$ month after delivery
\end{tabular}

Table 4: No of patients with frequent practice (FP) of EBMI

\begin{tabular}{ll}
\hline Items & N \\
\hline Frequent practice of EBMI (FP) & 36 \\
Not frequent practice of EBMI (Not FP) & 22 \\
Missing data & 6 \\
Total no of patients in intervention group & 64 \\
\hline
\end{tabular}


Table 5: Demographic data between intervention and control groups

\begin{tabular}{|c|c|c|c|}
\hline & $\begin{array}{l}\text { Intervention group } \\
(\mathrm{n}=64)\end{array}$ & $\begin{array}{l}\text { Control group } \\
(\mathrm{n}=56)\end{array}$ & $n$ \\
\hline & Mean (SD) & Mean (SD) & \\
\hline Age of pregnant & $33.34(4.11)$ & 33.84 (3.74) & .496 \\
\hline Age of husband & 36.77 (5.67) & $36.66(5.41)$ & .915 \\
\hline $\begin{array}{l}\text { Education } \\
\text { Middle school or below } \\
\text { High school } \\
\text { College or above }\end{array}$ & $\begin{array}{l}5(7.9 \%) \\
20(31.7 \%) \\
38(60.3 \%)\end{array}$ & $\begin{array}{l}8(14.5 \%) \\
19(34.5 \%) \\
28(50.9 \%)\end{array}$ & .428 \\
\hline $\begin{array}{l}\text { Employment } \\
\text { Full-time } \\
\text { Part-time } \\
\text { Housewife }\end{array}$ & $\begin{array}{l}56(87.5 \%) \\
3(4.7 \%) \\
5(7.8 \%)\end{array}$ & $\begin{array}{l}44(80 \%) \\
5(9.1 \%) \\
6(10.9 \%)\end{array}$ & .507 \\
\hline $\begin{array}{l}\text { Do exercise } \\
\text { No } \\
\text { Seldom } \\
\text { Often }\end{array}$ & $\begin{array}{l}6(9.5 \%) \\
47(74.6 \%) \\
10(15.9 \%)\end{array}$ & $\begin{array}{l}12(22.6 \%) \\
34(64.2 \%) \\
7(13.2 \%)\end{array}$ & .151 \\
\hline $\begin{array}{l}\text { Habit } \\
\text { Smoker } \\
\text { Non-smoker } \\
\text { Second-hand smoker }\end{array}$ & $\begin{array}{l}1(1.7 \%) \\
56(93.3 \%) \\
3(5 \%)\end{array}$ & $\begin{array}{l}1(1.9 \%) \\
50(96.2 \%) \\
1(1.9 \%)\end{array}$ & 680 \\
\hline $\begin{array}{l}\text { Past Health } \\
\text { No chronic disease } \\
\text { Surgery } \\
\text { Chronic disease } \\
\text { Psychiatric disease } \\
\quad \text { Sexual abuse at childhood }\end{array}$ & $\begin{array}{l}41(68.3 \%) \\
14(23.3 \%) \\
2(3.3 \%) \\
2(3.3 \%) \\
1(1.7 \%)\end{array}$ & $\begin{array}{l}37(74.0 \%) \\
12(24.0 \%) \\
1(1.2 \%) \\
0 \\
0\end{array}$ & .591 \\
\hline $\begin{array}{l}\text { Obstetric History } \\
\text { Para } 0 \\
\text { Para } 1 \\
\text { Para } 2 \text { or above } \\
\text { Previous CS* } \\
\quad 0 \\
=>1\end{array}$ & $\begin{array}{l}51(79.7 \%) \\
12(18.8 \%) \\
1(1.6 \%)\end{array}$ & $\begin{array}{l}40(71.4 \%) \\
10(17.9 \%) \\
6(10.7 \%)\end{array}$ & .102 \\
\hline $\begin{array}{l}\text { Past history of obstetric complications } \\
\text { Present history of obstetric complications } \\
\text { Yes } \\
\text { No }\end{array}$ & $\begin{array}{l}0 \\
2(3.1 \%) \\
62(96.9 \%)\end{array}$ & $\begin{array}{l}0 \\
0 \\
56(100 \%)\end{array}$ & $\begin{array}{l}\text { Nil } \\
.498\end{array}$ \\
\hline $\begin{array}{l}\text { Having pets at home } \\
\text { Yes } \\
\text { No }\end{array}$ & $\begin{array}{l}13(21.3 \%) \\
48(78.7 \%)\end{array}$ & $\begin{array}{l}7(13.5 \%) \\
45(86.5 \%)\end{array}$ & 0.276 \\
\hline $\begin{array}{l}\text { Planned pregnancy } \\
\text { Yes } \\
\text { No }\end{array}$ & $\begin{array}{l}56(87.5 \%) \\
8(12.5 \%)\end{array}$ & $\begin{array}{l}40(74.1 \%) \\
14(25.9 \%)\end{array}$ & .062 \\
\hline $\begin{array}{l}\text { Abuse during pregnancy } \\
\text { Yes } \\
\text { No }\end{array}$ & $\begin{array}{l}0 \\
61(100 \%)\end{array}$ & $\begin{array}{l}1(2.0 \%) \\
48(98.0 \%)\end{array}$ & .262 \\
\hline $\begin{array}{l}\text { Religion/Spirituality } \\
\text { Yes } \\
\text { No }\end{array}$ & $\begin{array}{l}37(58.7 \%) \\
26(41.3 \%)\end{array}$ & $\begin{array}{l}27(49.1 \%) \\
28(50.9 \%)\end{array}$ & .294 \\
\hline $\begin{array}{l}\text { Familial disease } \\
\text { Yes } \\
\text { No }\end{array}$ & $\begin{array}{l}23(40.4 \%) \\
34(59.6 \%)\end{array}$ & $\begin{array}{l}19(34.5 \%) \\
36(65.5 \%)\end{array}$ & .526 \\
\hline
\end{tabular}


Table 6: Comparison of prenatal coping inventory at $\mathrm{T} 1$ and $\mathrm{T} 2$

\begin{tabular}{|c|c|c|c|}
\hline Prenatal Coping Inventory & Intervention $(n=64)$ & Control $(n=56)$ & $p$ \\
\hline \multicolumn{4}{|l|}{ T1 } \\
\hline \multicolumn{4}{|l|}{ Prenatal coping inventory } \\
\hline Preparation for motherhood & $16.00(4.62)$ & $15.13(4.52)$ & .305 \\
\hline Avoidance & $7.10(3.60)$ & $6.62(3.60)$ & .474 \\
\hline Positive appraisal & $11.03(3.76)$ & $10.22(4.45)$ & .287 \\
\hline Prayer & $6.27(1.74)$ & $6.16(1.55)$ & .729 \\
\hline Seeking social support* & $5.90(1.40)$ & $5.29(1.10)$ & $.010 *$ \\
\hline Distraction & $1.73(1.49)$ & $1.56(1.49)$ & .546 \\
\hline Self-care** & $5.27(1.36)$ & $4.36(1.75)$ & $.002 * *$ \\
\hline Substance use & $1.21(1.30)$ & $0.96(1.14)$ & .285 \\
\hline \multicolumn{4}{|l|}{$\mathrm{T} 2$} \\
\hline \multicolumn{4}{|l|}{ Prenatal coping inventory } \\
\hline Preparation for motherhood & $15.45(4.59)$ & $14.56(4.87)$ & .308 \\
\hline Avoidance & $6.69(3.18)$ & $6.71(3.68)$ & .974 \\
\hline Positive appraisal & 10.95 (3.97) & $10.02(4.51)$ & .229 \\
\hline Prayer & $6.16(1.65)$ & $5.80(1.65)$ & .243 \\
\hline Seeking social support** & $5.41(1.50)$ & $4.66(1.28)$ & $.004^{* *}$ \\
\hline Distraction & $1.59(1.42)$ & $1.43(1.50)$ & .537 \\
\hline Self-care** & $4.66(1.37)$ & $3.71(1.73)$ & $.001^{* *}$ \\
\hline Substance use & $1.10(1.01)$ & $0.82(1.05)$ & .150 \\
\hline Prenatal Coping Inventory & FP $(n=36)$ & Control $(n=56)$ & $p$ \\
\hline \multicolumn{4}{|l|}{$\mathrm{T} 1$} \\
\hline \multicolumn{4}{|l|}{ Prenatal coping inventory at $\mathrm{T} 1$} \\
\hline Preparation for motherhood & [2] $15.44(4.37)$ & [1] 15.13 (4.52) & .748 \\
\hline Avoidance & [1] $7.29(3.26)$ & [1] $6.62(3.60)$ & .377 \\
\hline Positive appraisal & [2] $11.35(4.16)$ & [1] $10.22(4.45)$ & .234 \\
\hline Prayer & [1] $6.29(1.93)$ & [1] $6.16(1.55)$ & .742 \\
\hline Seeking social support* & [1] $5.91(1.50)$ & [1] $5.29(1.10)$ & $.038 *$ \\
\hline Distraction & [1] $1.80(1.43)$ & [1] $1.56(1.49)$ & .458 \\
\hline Self-care* & [1] $5.20(1.37)$ & [1] $4.36(1.75)$ & $.018^{*}$ \\
\hline Substance use & [1] $0.97(1.04)$ & [1] $0.96(1.14)$ & .974 \\
\hline \multicolumn{4}{|l|}{$\mathrm{T} 2$} \\
\hline \multicolumn{4}{|l|}{ Prenatal coping inventory at $\mathrm{T} 2$} \\
\hline Preparation for motherhood & $15.22(3.80)$ & [1] $14.56(4.87)$ & .495 \\
\hline Avoidance & [1] $7.14(3.40)$ & $6.71(3.68)$ & .579 \\
\hline Positive appraisal* & $11.94(3.95)$ & $10.02(4.51)$ & $.039 *$ \\
\hline Prayer & [1] $6.23(1.50)$ & $5.80(1.65)$ & .218 \\
\hline Seeking social support** & $5.64(1.42)$ & $4.66(1.28)$ & $.001^{* *}$ \\
\hline Distraction & $1.72(1.54)$ & $1.43(1.50)$ & .367 \\
\hline Self-care** & $4.94(1.31)$ & $3.71(1.73)$ & $.000^{* *}$ \\
\hline Substance use & $1.00(0.96)$ & $0.82(1.05)$ & .411 \\
\hline Prenatal Coping Inventory & FP $(n=36)$ & Not FP $(n=22)$ & $p$ \\
\hline \multicolumn{4}{|l|}{ T1 } \\
\hline \multicolumn{4}{|l|}{ Prenatal coping inventory } \\
\hline Preparation for motherhood & [2] $15.44(4.37)$ & $16.5(5.32)$ & .420 \\
\hline Avoidance & [1] $7.29(3.26)$ & $6.86(3.82)$ & .658 \\
\hline Positive appraisal & [2] $11.35(4.16)$ & [1] $10.38(3.41)$ & .372 \\
\hline Prayer & [1] $6.29(1.93)$ & $6.41(1.53)$ & .801 \\
\hline Seeking social support & [1] $5.91(1.50)$ & $5.82(1.33)$ & .807 \\
\hline Distraction & [1] $1.80(1.43)$ & $1.59(1.37)$ & .587 \\
\hline Self-care & [1] $5.20(1.37)$ & $5.27(1.24)$ & .840 \\
\hline Substance use & [1] $0.97(1.04)$ & $1.50(1.54)$ & .127 \\
\hline \multicolumn{4}{|l|}{$\mathrm{T} 2$} \\
\hline \multicolumn{4}{|l|}{ Prenatal coping inventory T2 } \\
\hline Preparation for motherhood & $15.22(3.80)$ & $16.64(5.70)$ & .309 \\
\hline Avoidance & [1] $7.14(3.40)$ & $6.36(2.99)$ & .381 \\
\hline Positive appraisal* & $11.94(3.95)$ & $9.77(3.41)$ & $.037^{*}$ \\
\hline Prayer & [1] $6.23(1.50)$ & $6.36(1.43)$ & .737 \\
\hline Seeking social support & $5.64(1.42)$ & $5.36(1.26)$ & .457 \\
\hline Distraction & $1.72(1.54)$ & $1.41(1.37)$ & .437 \\
\hline Self-care & $4.94(1.31)$ & $4.59(1.14)$ & .300 \\
\hline Substance use & $1.00(0.96)$ & $1.23(1.19)$ & .428 \\
\hline
\end{tabular}

[ ] = no of missing data; ${ }^{* *} p<.01,{ }^{*} p<.05$ 
Table 7: Comparison of EPDS at T1, T2 and T3

\begin{tabular}{llll}
\hline $\begin{array}{l}\text { Edinburgh postnatal } \\
\text { depression scale (EPDS) }\end{array}$ & $\begin{array}{l}\text { Intervention } \\
\mathbf{( n = 6 4 )}\end{array}$ & $\begin{array}{l}\text { Control } \\
\mathbf{( n = 5 6 )}\end{array}$ & $\boldsymbol{p}$ \\
\cline { 2 - 4 } & Mean (SD) & Mean (SD) & \\
\hline T1 & {$[1] 7.95(3.58)$} & $6.96(3.94)$ & .154 \\
T2 & $6.77(3.79)$ & {$[4] 6.50(3.32)$} & .692 \\
T3 & {$[17] 6.62(3.93)$} & {$[7] 6.31(4.56)$} & .722 \\
\hline & Frequent practice & Control & \\
& $(\mathbf{n = 3 6 )}$ & $\mathbf{( n = 5 6 )}$ & \\
\hline T1 & {$[1] 7.46(3.50)$} & $6.96(3.94)$ & .546 \\
T2 & $6.64(3.84)$ & {$[4] 6.50(3.32)$} & .857 \\
T3 & {$[9] 6.04(3.51)$} & {$[7] 6.31(4.56)$} & .791 \\
\hline & Frequent practice & $\begin{array}{l}\text { Not FP } \\
\text { (n=22) }\end{array}$ & $\boldsymbol{p}$ \\
\hline T1 & (FP) (n= 36) & $8.23(3.62)$ & .428 \\
T2 & {$[1] 7.46(3.50)$} & $6.95(4.02)$ & .766 \\
T3 & $6.64(3.84)$ & {$[7] 7.53(5.06)$} & .320 \\
\hline
\end{tabular}

[ ] = no of missing data

Quantitative results from the increase in mindfulness and positive affect and the decrease in pregnancy anxiety, depression and negative affect. Byrne et al. ${ }^{[97]}$ developed a mindfulness- and skills-based antenatal education program (MBCE) for pregnant women and their birth support partners which aimed at increasing the health literacy and resilience of women and their birth partners as a possible way of preventing post-natal depression, maternal dissatisfaction with labour and maternal/paternal stress, which is linked to a range of negative child development outcomes.

Robledo-Colonia et al. ${ }^{[190]}$ found that aerobic exercise training during pregnancy reduces depressive symptoms in nulliparous women. Satyapriya et al. ${ }^{[191]}$ studied the effect of integrated yoga on pregnancy experience, anxiety, and depression in normal pregnancy and found out that the intervention reduces anxiety, depression and pregnancy related uncomfortable experiences. Youngwanichsetha et al..$^{[113]}$ found that mindfulness eating and yoga exercise had health benefits on glycemic control in pregnant women with gestational diabetes mellitus.

Pregnant women face a considerable amount of stress during perinatal period because of the emotional, physical, and interpersonal changes. Stress and coping is the point where interventions take place. The cycle of stress and the ineffective use of coping resources of pregnant women can adversely affect the development life course of the pregnant woman, birth outcomes, and her infant. ${ }^{[103,192]}$ Interventions during the perinatal period are the best way to strengthen the coping strategies and stress management for pregnant women with better outcomes. ${ }^{[103,159,191,193]}$ Present study showed that EBMI may have effect on coping mechanism through improvement in positive appraisal as shown in Prenatal Coping Inventory in FP group at T2 when compared with control and Not FP group $(p<.05)$ (see
Table 6). Present intervention may be effective in promoting maternal health through improved stress-coping mechanism. ${ }^{[15,194,195]}$ The positive effect of EBMI in the present study may provide a foundation for future development of effective intervention in perinatal emotional problems.

Most of the randomized controlled trials examined the effectiveness of antenatal group interventions at preventing postnatal depression in "at risk" women. ${ }^{[100,189,196-199]}$ Duncan \& Bardacke ${ }^{[189]}$ reported that participants in the Mindfulness-Based Childbirth and Parenting (MBCP) program will have decrease in pregnancy anxiety, depression and negative affect. Carolan et al. ${ }^{[200]}$ found that singing is an activity with stress reducing and other benefits for pregnant women with stress. Present study indicated no difference in depressive symptoms in EPDS (see Table 7) between intervention and control group at $\mathrm{T} 2$ and $\mathrm{T} 3$. It is probably because EBMI is intended to promote maternal health and fetal health, but not to treat depression. To emphasize the psychoeducational nature of the intervention, participants were invited to attend the EBMI "course", not to enter "therapy". Present research is not intended to identify a group at high imminent risk of peri-partum depression and determine whether the intervention reduces incidence in comparison with to a control group. Another reason for no significant group effect on depressive symptoms is that depressive symptoms of the participants in the intervention and control group tested using EPDS (see Table 7) showed no significant differences between the groups and there was no suspected case identified that required further referral. Small sample size and too many missing data at T3 may also contribute to the no reduction in depressive symptoms.

Cortisol level in hair, plasma, urine and saliva are index for psychological status in pregnant women despite the systemic alterations associated with the endocrinology of pregnancy. ${ }^{[37,161,201-206]}$ Shea et al. ${ }^{[123]}$ using salivary cortisol to investigate the cortisol awakening response in pregnant women in relation to stress found significant associations between baseline awakening cortisol levels at 20 weeks of gestation and early life trauma, but not with depression or anxiety. Pluess et al. ${ }^{[122]}$ reported that maternal trait anxiety proved related to all stress-related psychological measures and high anxiety predicted low baseline cortisol awakening levels in early pregnancy. Ventura et al. ${ }^{[207]}$ revealed that a relaxing intervention as short as $30 \mathrm{~min}$ like listening to music, decreases plasma cortisol and self-reported state anxiety score for pregnant women awaiting amniocentesis. Pluess et al. ${ }^{[208]}$ found that positive life events in pregnant women predicted lower third-trimester baseline awakening cortisol levels. O'Donnell et al.$^{[34]}$ testified that there are small but persisting associations between maternal prenatal mood and diurnal cortisol in the child that persist into adolescence and may constitute a programming effect. 
Table 8: Comparison of BMSWBI at T1, T2, T3 and T4 (FP and Control)

\begin{tabular}{|c|c|c|c|}
\hline BMSWBI & FP $(n=36)$ & Control $(n=56)$ & $p$ \\
\hline \multicolumn{4}{|l|}{$\mathrm{T} 1$} \\
\hline Physical distress & [1] 28.66 (17.30) & [2] 28.57 (19.68) & .984 \\
\hline Daily functioning & [1] 62.49 (13.43) & [2] $61.44(14.94)$ & .734 \\
\hline \multicolumn{4}{|l|}{ Affect } \\
\hline Negative affect & [1] 28.69 (18.25) & 25.45 (18.94) & .423 \\
\hline Positive affect & [2] 55.85 (12.75) & [2] 51.69 (12.28) & .130 \\
\hline Total score & [2] 137.12 (24.59) & [2] 135.74 (26.96) & .810 \\
\hline \multicolumn{4}{|l|}{ Spirituality } \\
\hline Tranquility & [1] $26.11(7.58)$ & $25.82(7.42)$ & .856 \\
\hline Disorientation & [1] $4.71(5.72)$ & $3.64(5.91)$ & .396 \\
\hline Resilience* & [1] $22.03(5.84)$ & [1] $19.22(6.52)$ & $.041 *$ \\
\hline Total score & [1] $93.43(15.27)$ & [1] 91.24 (15.74) & .516 \\
\hline Total score for BMSWBI & [3] $400.73(55.35)$ & [6] 399.18 (63.55) & .909 \\
\hline \multicolumn{4}{|l|}{$\mathrm{T} 2$} \\
\hline Physical distress & [1] 29.14 (17.04) & $26.93(21.31)$ & .605 \\
\hline Daily functioning & $61.06(16.01)$ & [1] 58.69 (16.58) & .502 \\
\hline \multicolumn{4}{|l|}{ Affect } \\
\hline Negative affect & $25.44(17.00)$ & $24.64(18.95)$ & .837 \\
\hline Positive affect & $54.92(14.20)$ & [1] 49.95 (12.80) & .086 \\
\hline Total score & $139.47(25.47)$ & [1] $135.58(24.38)$ & .467 \\
\hline \multicolumn{4}{|l|}{ Spirituality } \\
\hline Tranquility & $27.14(7.52)$ & $25.86(7.44)$ & .424 \\
\hline Disorientation & $3.03(5.52)$ & $2.88(5.39)$ & .896 \\
\hline Resilience* & $21.25(5.19)$ & $18.54(6.81)$ & $.044^{*}$ \\
\hline Total score & $95.36(14.96)$ & $91.52(15.47)$ & .242 \\
\hline Total score for BMSWBI & [1] 408.54 (58.56) & [2] 400.43 (64.29) & .549 \\
\hline \multicolumn{4}{|l|}{ T3 } \\
\hline Physical distress* & [9] 27.04 (18.23) & [8] $18.29(14.96)$ & $.028 *$ \\
\hline Daily functioning & [8] 54.75 (14.35) & [9] 58.62 (17.14) & .320 \\
\hline \multicolumn{4}{|l|}{ Affect } \\
\hline Negative affect & [8] 30.04 (18.96) & [7] 24.65 (21.38) & .272 \\
\hline Positive affect & [8] $53.79(13.94)$ & [8] $50.40(15.57)$ & .345 \\
\hline Total score & [8] 133.75 (30.55) & [8] $135.44(32.90)$ & .825 \\
\hline \multicolumn{4}{|l|}{ Spirituality } \\
\hline Tranquility & [8] 26.75 (8.18) & [7] $25.71(7.76)$ & .582 \\
\hline Disorientation & [8] $3.50(5.33)$ & [8] $4.08(6.79)$ & .698 \\
\hline Resilience & [8] 20.07 (6.30) & [7] $20.76(5.62)$ & .624 \\
\hline Total score & [8] $93.32(15.87)$ & [7] $92.29(17.17)$ & .795 \\
\hline Total score for BMSWBI & [9] $397.48(60.05)$ & [12] 408.45 (70.82) & .505 \\
\hline \multicolumn{4}{|l|}{$\mathrm{T} 4$} \\
\hline Physical distress & [12] $28.42(24.43)$ & [9] 21.81 (16.48) & .181 \\
\hline Daily functioning & [13] $60.96(16.86)$ & [9] 60.68 (15.67) & .946 \\
\hline \multicolumn{4}{|l|}{ Affect } \\
\hline Negative affect & [12] $29.96(24.01)$ & [9] 24.04 (18.87) & .259 \\
\hline Positive affect & [12] 56.33 (13.14) & [10] 50.17 (15.42) & .100 \\
\hline Total score & [12] 136.38 (33.13) & [10] 135.76 (28.75) & .936 \\
\hline \multicolumn{4}{|l|}{ Spirituality } \\
\hline Tranquility & [12] 26.79 (8.54) & [9] $26.72(7.22)$ & .972 \\
\hline Disorientation & [12] $5.79(9.74)$ & [9] $5.72(10.61)$ & .979 \\
\hline Resilience & [12] $21.58(6.43)$ & [9] $20.04(6.04)$ & .323 \\
\hline Total score & [12] 92.58 (19.62) & [9] 91.04 (18.47) & .746 \\
\hline Total score for BMSWBI & [13] 406.61 (73.08) & [10] $404.98(66.44)$ & .926 \\
\hline
\end{tabular}

[ ] = no of missing data; ${ }^{*} p<.05$ 
Table 9: Comparison of maternal salivary cortisol level at T1, T2, T3 and T4

\begin{tabular}{|c|c|c|c|}
\hline \multirow[t]{2}{*}{ Maternal Salivary Cortisol } & $\begin{array}{l}\text { Intervention } \\
(n=64)\end{array}$ & $\begin{array}{l}\text { Control } \\
(n=56)\end{array}$ & \multirow[t]{2}{*}{$p$} \\
\hline & Mean (SD) & Mean (SD) & \\
\hline \multicolumn{4}{|l|}{$\mathrm{T} 1$} \\
\hline Morning & 10.58 (5.09) & $11.86(5.12)$ & .183 \\
\hline Evening* & 1.35 (1.16) & 1.86 (1.39) & $.033 *$ \\
\hline Mean & $5.97(2.71)$ & $6.87(2.66)$ & .079 \\
\hline \multicolumn{4}{|l|}{$\mathrm{T} 2$} \\
\hline Morning & $9.91(5.40)$ & $9.97(4.42)$ & .947 \\
\hline Evening & $3.65(2.25)$ & $3.68(2.36)$ & .957 \\
\hline Mean & $6.77(3.24)$ & $6.75(2.59)$ & .969 \\
\hline \multicolumn{4}{|l|}{$\mathrm{T} 3$} \\
\hline Morning & $6.25(4.18)$ & $7.42(6.43)$ & .337 \\
\hline Evening & $0.70(0.87)$ & $1.40(2.24)$ & .080 \\
\hline Mean & $3.46(2.15)$ & $4.31(3.60)$ & .221 \\
\hline \multicolumn{4}{|l|}{$\mathrm{T} 4$} \\
\hline Morning & $6.62(5.45)$ & $6.00(5.16)$ & .595 \\
\hline Evening & $1.08(1.60)$ & $1.81(3.65)$ & .249 \\
\hline Mean & $3.91(3.11)$ & $3.94(3.92)$ & .964 \\
\hline \multirow[t]{2}{*}{ Maternal Salivary Cortisol } & $\begin{array}{l}\text { FP } \\
(n=36)\end{array}$ & $\begin{array}{l}\text { Control } \\
(n=56)\end{array}$ & \multirow[t]{2}{*}{$p$} \\
\hline & Mean (SD) & Mean (SD) & \\
\hline \multicolumn{4}{|l|}{$\mathrm{T} 1$} \\
\hline Morning & [2] $10.32(4.63)$ & [3] $11.86(5.12)$ & .158 \\
\hline Evening & [3] $1.46(1.33)$ & [1] $1.86(1.39)$ & .190 \\
\hline Mean & [3] 5.90 (2.32) & [3] 6.87 (2.66) & .097 \\
\hline \multicolumn{4}{|l|}{$\mathrm{T} 2$} \\
\hline Morning & [3] $9.56(5.60)$ & [1] 9.97 (4.42) & .708 \\
\hline Evening & [3] 3.97 (2.68) & [6] 3.68 (2.36) & .600 \\
\hline Mean & [3] 6.76 (3.46) & [7] 6.75 (2.59) & .984 \\
\hline \multicolumn{4}{|l|}{ Т3 } \\
\hline Morning & [11] $6.16(4.22)$ & [18] 7.42 (6.43) & .389 \\
\hline Evening* & [11] $0.60(0.67)$ & [18] $1.40(2.24)$ & $.046 *$ \\
\hline Mean & [11] 3.38 (2.16) & [19] 4.31 (3.60) & .254 \\
\hline \multicolumn{4}{|l|}{$\mathrm{T} 4$} \\
\hline Morning & [11] 5.77 (5.49) & [15] $6.00(5.16)$ & .869 \\
\hline Evening & [11] $0.92(1.40)$ & [15] 1.81 (3.65) & .270 \\
\hline Mean & [13] 3.43 (3.14) & [17] 3.94 (3.92) & .597 \\
\hline
\end{tabular}

[ ] = no of missing data; ${ }^{*} p<.05$

These findings suggest that positive experiences are of relevance and reflecting a resource with potentially beneficial effects for the mother and the development fetus. It might be promising for psychological intervention programs to focus on increasing positive experiences of the expecting mother rather than exclusively trying to reduce maternal stress during pregnancy.Present study did not show any difference in maternal salivary cortisol level between intervention and control group at T1, T2, T3 and T4. This is not unexpected as present research showed no difference in depres- sive symptoms in EPDS (see Table 7) between intervention and control group at $\mathrm{T} 1$ and $\mathrm{T} 2$. Both groups are mentally healthy at start and there was no suspected case identified that required further referral.

Present research indicated that the control group had a steeper decline in diurnal salivary cortisol level as compared with FP group at T3 $(p<.05)$ (see Table 8). The significance of this finding may indicate perinatal meditation have beneficial effects on postnatal mental health. Small sample size and too many missing data at $\mathrm{T} 3$ and $\mathrm{T} 4$ may affect the 
results of present research.

Postnatal care is important but women have consistently rated postnatal care less favorably than other episodes of maternity care. ${ }^{[78,209,210]}$ Present study find out that perinatal meditation can help pregnant women to reduce stress in postnatal period as shown by the control group had a steeper decline in diurnal salivary cortisol level as compared with FP group at T3 (see Table 8). The score on physical distress (BMSWI) between FP and control group at T3 is of statistical significant $(p<.05)$ (see Table 8) implied that EBMI may decrease postnatal physical distress which are risk factors for maternal health, fetal health and future child health. The design of EBMI is based on the chance of practice on daily basis and incorporates into the daily activities of the participants. ${ }^{[12,113]}$ There were more than $60 \%$ of participants who practice EBMI frequently (FP group) as compared with other interventions. ${ }^{[25,188,199,204,211,212]}$ Frequency of practice is the key point for the success of any intervention provided. As shown by present research, only the FP group have improvement when compared with control but not the intervention group or Not FP group.

One of the limitations in present research is using convenience sample. Another limitation of present research is that with a relatively long recruitment period, the findings must be interpreted cautiously. Too much missing data at

\section{References}

[1] Carolan, M., \& Barry, M. Antenatal stress: An Irish case study. Midwifery. 2014; 30: 310-316. PMID:23684696 http://dx .doi.org /10.1016/j.midw.2013.03.014

[2] Ruiz, R.J., \& Fullerton, J.T. The measurement of stress in pregnancy. Nurs Health Sci. 1999; 1: 19-25. PMID:10894648 http: //dx.doi.org/10.1046/j.1442-2018.1999.00004.x

[3] Chalem, E., Mitsuhiro, S.S., Manzolli, P., et al. Underdetection of Psychiatric disorders during prenatal care: A Survey of Adolescents in Sao Paulo, Brazil. Journal of Adolescent Health. 2012; 40: 9396. PMID:22188840 http://dx.doi.org/10.1016/j.jadohea Ith. 2011.03 .012

[4] Rubertsson, C., Waldenstrom, U., \& Wickberg, B. Depressive mood in early pregnancy: prevalence and women at risk in a national Swedish sample. Journal of Reproductive and Infant Psychology. 2003; 21(2): 113-123. http://dx.doi.org/10.1080/0264683 031000124073

[5] Van Bussel, J., Spitz, B., \& Demyttenaere, K. Women's mental health before, during, and after pregnancy: a population-based controlled cohort study. Birth. 2006; 33(4): 297-302. PMID:17150068 http://dx.doi.org/10.1111/j.1523-536X.2006.00122.x

[6] Woods, S. M., Melville, J. L., Guo, Y., Fan, M. Y., \& Gavin, A. Psychosocial stress during pregnancy. Am J Obstet Gynecol. 2010; 202(61): e1-e7. PMID:19766975 http://dx.doi.org/10.1016 /j.ajog.2009.07.041

[7] Kuo, S.H., Wang, R.H., Tseng, H.C., Jian, S.Y.,\& Chou, F. H. A Comparision of Different Severities of Nausea and Vomiting During Pregnancy Relative to Stress, Social Support, and Maternal Adaptation. Journal of Midwifery \& Women's Health. 2007; 52(1): e1-
T3 and T4 also lead to the difficulties in interpreting the results. Meditation research in addition has suffered from significant methodological and conceptual limitations. Present study found that there are insufficient existing instruments to measure positive health markers in normal population in order to assess the effectiveness of interventions in holistic dimensions.

\section{Implications}

Perinatal meditation can be added into present prenatal counselling and prenatal and postnatal program to promote pregnancy health, child health and family health. ${ }^{[75,85,213-215]}$ This model of intervention serves as a good example of preventive medicine (Sado et al., 2014). Healthcare providers should provide meditation as complementary therapy for women's other life events like preconception, infertility, pregnancy loss and peri-menopausal life time. ${ }^{[216-220]}$

\section{Acknowledgements}

The study was funded by the Centre of Buddhist Studies, University of Hong Kong.

\section{Conflicts of Interest Disclosure}

The authors declare no conflict of interest. e7. PMID:17207743 http://dx.doi.org/10.1016/j.jmwh. 20 06.10 .002

[8] Locock, L., Alexander, J., \& Rozmovits, L. Women's responses to nausea and vomiting in pregnancy. Midwifery. 2008; 24: 143152. PMID:17316935 http://dx.doi.org/10.1016/j.midw. 2006.12.001

[9] Swallow, B.L., Lindow, S.W., Masson, E.A., \& Hay, D.M. Psychological health in early pregnancy: relationship with nausea and vomiting. J Obstet Gynaecol. 2004; 24: 28-32. PMID:14675977 http://dx.doi.org/10.1080/01443610310001620251

[10] Burkhardt, T., Schwabe, S., Morgenthaler, N., Natalucci, G., Zimmermann, R., \& Wellmann, S. Copetin: a marker for stress reaction in fetuses with intrauterine growth restriction. Am J Obstet Gynecol. 2012; 207: 497.e1-5. PMID:23089587 http://dx.doi.org/10. $1016 / j$.ajog. 2012.09.024

[11] Christian, L.M. Psychoneuroimmunology in pregnancy: Immune pathways linking stress with maternal health, adverse birth outcomes, fetal development. Neuroscience \& Biobehavioral Reviews. 2012; 36: 350-361. PMID:21787802 http://dx.doi.org/10. 1016/j.neubiorev. 2011.07.005

[12] Furber, C., Garrod, D., Maloney, E., Lovell, K., \& McGowan, L. A qualitative study of mild to moderate psychological distress during pregnancy. International Journal of Nursing Studies. 2009; 46: 669-677. PMID:19150062 http://dx.doi.org/10.1016/j .ijnurstu.2008.12.003

[13] Kreither, M., Cage, C., Cole, S., Brandt, C., Lobel, M. \& CoussonsRead, M.E. Higher acculturation and lower pregnancy-specific stress is correlated with lower incidence of pregnancy complications in Latinas. Brain, Behavior, and Immunity. 2009; 23: s44. http://dx.doi.org/10.1016/j.bbi.2009.06.074 
[14] Parker, V.J., \& Douglas, A.J. Stress in early pregnancy: maternal neuro-endocrine-immune responses and effects. Journal of Reproductive Immunology. 2010; 85: 86-92. PMID:20079933 http: //dx.doi.org/10.1016/j.jri.2009.10.011

[15] Sharma, N., \& Gedeon, T. Modeling a stress signal. Applied Soft Computing. 2014; 14: 53-61. http://dx.doi.org/10.1016/j .asoc. 2013.09.019

[16] Wisborg, K., Barklin, A., Hedegaard, M., \& Henriksen, T. Psychological stress during pregnancy and stillbirth: prospective study. BJOG. 2008; 115: 882-885. PMID:18485167 http://dx.doi.o $\mathrm{rg} / 10.1111 / \mathrm{j} .1471-0528.2008 .01734 . \mathrm{x}$

[17] Brummelte, S., \& Galea, L.A.M. Depression during pregnancy and postpartum: Contribution of stress and ovarian hormones. Progress in Neuro-Psychopharmacology \& Biological Psychiatry, available online 12 September 2009.

[18] Coussons-Read, M.E., Lobel, M., Carey, J.C., et al. The occurrence of preterm delivery is linked to pregnancy-specific distress and elevated inflammatory markers across gestation. Brain, Behavior, and Immunity. 2012; 26: 650-659. PMID:22426431 http: //dx.doi.org/10.1016/j.bbi.2012.02.009

[19] Lau, Y., Wong, F. K., Wang, Y., Kwong, H. K., \& Wang, Y. The roles of social support in helping Chinese women with antenatal depressive and anxiety symptoms cope with perceived stress. Archives of Pyschiatric Nursing. 2014. http://dx.doi.org/10.1016/j .apnu. 2014.05.009

[20] Liou, S. R., Wang, P., \& Cheng, C. Y. Longitudinal study of perinatal maternal stress, depressive symptoms and anxiety. Midwifery. 2014; 30: 795-801. PMID:24342423 http://dx.doi.org/10.10 16/j.midw. 2013.11.007

[21] Martini, J., Knappe, S., Beesdo-Baum, K., Lieb, R., \& Wittchen, H-U. Anxiety disorders before birth and self-perceived distress during pregnancy: Associations with maternal depression and obstetric, neonatal and early childhood outcomes. Early Human Development. 2010; 86: 305-310. PMID:http://dx.doi.org/10.1016/j.earlhumdev.2010.04.004 205470 16

[22] Wadhwa, P.D., Entringer, S., Buss, C. \& Lu, M. The Contribution of Maternal Stress to Preterm Birth: Issues and Considerations. Clinics in Perinatology. 2011; 38(3): 351-384. PMID:21890014 http://dx.doi.org/10.1016/j.clp.2011.06.007

[23] Wainstock, T., Lemer-Geva, L., Glasser, S., Shoham-Vardi, I., \& Anteby, E. 727: Prenatal maternal stress associated with potentially life threatening situations and preterm birth and low birthweight. American Journal of Obstetrics \& Gynaecology. 2013; 208(1): S306. http://dx.doi.org/10.1016/j.ajog.2012.10.065

[24] Zhu, P., Tao, F., Hao, J., Sun, Y., \& Jiang, X. Prenatal life events stress: implications for preterm birth and infant birthweight. American Journal of Obstetrics \& Gynaecology. 2010; 203(1): 34.e1-34.e8. PMID:20417475 http://dx.doi.org/10.1016/j .ajog. 2010.02 .023

[25] Dasari, P., \& Kodenchery, M.M. Psychological factors in preterm labor and psychotherapeutic intervention. International Journal of Gynaecology \& Obstetrics. 2007; 97 (3): 196-197. PMID:17459389 http://dx.doi.org/10.1016/j.ijgo.2007.03.006

[26] Hoffman, C., D’Anna, K., Coussons-Read, M.E., Ross, R.G., \& Laudenslager, M.L. The relationship between pernatal stress, maternal salivary cortisol, and preterm birth. AJOG. 2011; 204(1): s187. http://dx.doi.org/10.1016/j.ajog.2010.10.486

[27] Latendresse, G. The interaction Between Chronic Stress and Pregnancy: Preterm Birth from A Biobehavioral Perspective. Journal of Midwifery \& Women's Health. 2009; 54(1): 8-17. PMID:19114234 http://dx.doi.org/10.1016/j.jmwh.2008.08.001

[28] Lobel, M., Cannella, D.L., Graham, et al. Pregnancy specific stress, prenatal health behaviors and birth outcomes. Health Psychology. 2008; 27(5): 604-615. PMID:18823187 http://dx.doi.org/1 $0.1037 / \mathrm{a} 0013242$

[29] Suri, R., Altshuler, L., Hellemann, G., Burt, V. K., Aquion, A., \& Mintz, J. Effects of antenatal depression and antidepressant treatment on gestational age at birth and risk of preterm birth. Am
J Psychiatry. 2007; 164(8): 1206-1213. PMID:17671283 http: //dx.doi.org/10.1176/appi.ajp. 2007.06071172

[30] Glynn, L. M., Schetter, C. D., Hobel, C. J., \& Sandman, C. A. Pattern of perceived stress and anxiety in pregnancy predicts preterm birth. Health Psychology. 2008; 27(1): 43-51. PMID:18230013 http://dx.doi.org/10.1037/0278-6133.27.1.43

[31] Giesbrecht, G.F., Campbell, T., Letourneau, N., Kooistra, L., Kaplan, B. Psychological distress and salivary cortisol covary within persons during pregnancy. Psychoneuroendocrinology. 2012; 37: 270-279. PMID:21752548 http://dx.doi.org/10.1016/j .psyneuen.2011.06.011

[32] Giesbrecht, G.F., Campbell, T., Letourneau, N., Kaplan, B.J. \& the APrON Study Team. Advancing gestation does not attenuate biobehavioural coherence between psychological distress and cortisol. Biological Psychology. 2013; 93: 45-51.PMID:23410761 http: //dx.doi.org/10.1016/j.biopsycho.2013.01.019

[33] Weinstock, M. The long-term behavioural consequences of prenatal stress. Neuroscience \& Biobehavioral Reviews. 2008; 32: 10731086. PMID:18423592 http://dx.doi.org/10.1016/j.neubi orev. 2008.03 .002

[34] O’Donnell, K.J., Glover, V., Jenkins, J., et al. Prenatal maternal mood is associated with altered diurnal cortisol in adolescence. Psychoneuroendocrinology. 2013; 38(9): 1630-1638. PMID:23433748 http://dx.doi.org/10.1016/j.psyneuen.2013.01.008

[35] Entringer, S., Epei, E., Kumsta, R., Lin, J., Hellhammer, D., Blackburn, E., et al. Stress exposure in intrauterine life is associated with shorter telomere length in young adulthood. Proceedings of the National Academy of Sciences. 2011; 108(33): E513-E518. PMID:21813766 http://dx.doi.org/10.1073/pnas.110775 9108

[36] Bergman, K., Sarkar, P., O’Connor, T.G., Modi, N. \& Glover, V. Maternal stress during pregnancy predicts cognitive ability and fearfulness in infancy. Journal of the American Academy of Child \& Adolescent Psychiatry. 2007; 46(11): 1454-1463. PMID:18049295 http://dx.doi.org/10.1097/chi.0b013e31814a62f6

[37] Bolten, M., Nast, I., Skrundz, M., Stadler, C., Helhammer, D., \& Meinlschmidt, G. Prenatal programming of emotion regulation: Neonatal reactivity as a differential susceptibility factor moderating the outcome of prenatal cortisol levels. Journal of Psychosomatic Research. 2013; 75(4): 351-357. PMID:24119942 http: //dx.doi.org/10.1016/j.jpsychores.2013.04.014

[38] Buss, C., Davis, E.P., Muftuler, L.T., Head, K. \& Sandman, C.A. High pregnancy anxiety during mid-gestation is associated with decreased gray matter density in 6-9 year-old children. Psychoneuroendocrinology. 2010; 35: 141-153. PMID:19674845 http:// dx.doi.org/10.1016/j.psyneuen.2009.07.010

[39] Charil, A., Laplante, D.P., Vaillancourt, C., \& King, S. Prenatal Stress and Brain Development. Brain Research Reviews. 2010; 65(1): 56-79. PMID:20550950 http://dx.doi.org/10.1016/j .brainresrev.2010.06.002

[40] Chuang, C. H. Chen, P.C. Prenatal stress and child behavior: a prospective birth cohort study in Taiwan. Early Human Development. 2007; 83(1): s115. http://dx.doi.org/10.1016/S0378 $-3782(07) 70284-0$

[41] Cottrell, E.C. Seckl, J.R. Prenatal stress, glucocorticoids and the programming of adult disease. Front Behav Neurosci. 2009; 3: 19.

[42] Deave, T., Heron, J., Evans, J. Emond, A. The impact of maternal depression in pregnancy on early child development. BJOG. 2008; 15: 043-1051. PMID:18651886 http://dx.doi.org/10. 1111/j.1471-0528.2008.01752.x

[43] Dietro, J.A. Maternal Stress in Pregnancy: Considerations for Fetal Development. Journal of Adolescent Health. 2012; 51: s3s8. PMID:22794531 http://dx.doi.org/10.1016/j.jadohea 1th. 2012.04.008

[44] Ehlert, U. Understanding the trans-generational consequences of prenatal stress. Journal of Psychosomatic Research. 2013; 75: 297298. PMID:24119933 http://dx.doi.org/10.1016/j.jpsyc hores.2013.09.002 
[45] Giudice, M.D. Fetal programming by maternal stress: Insights from a conflict perspective. Psychoeuroendocrinology. 2012; 37: 16141629. PMID:22694951 http://dx.doi.org/10.1016/j.psyne uen. 2012.05.014

[46] Glover, V., O'Connor, T.G. O'Donnel, K. Prenatal stress and the programming of the HPA axis. Neuroscience \& Biobehavioral Reviews. 2012; 35: 17-22. PMID:19914282 http://dx.doi.org/1 $0.1016 / j$.neubiorev. 2009.11.008

[47] Graignic-Philippe, R., Dayan, J., Chokron, S., Jacquet, A-Y., \& Tordjman, S. Effects of prenatal stress on fetal and child development: A critical literature review. Neuroscience \& Biobehavioral Reviews. 2014; 43: 137-162. PMID:24747487 http://dx.doi.o $\mathrm{rg} / 10.1016 / \mathrm{j} \cdot$ neubiorev $\cdot 2014.03 .022$

[48] Harris, A. Seckl, J. Glucocorticoids, prenatal stress and the programming of disease. Hormones \& Behavior. 2011; 59: 279289. PMID:20591431 http://dx.doi.org/10.1016/j.yhbeh .2010 .06 .007

[49] Howerton, C.L. Bale, T.L. Prenatal programming: At the intersection of maternal stress \& immune activation. Hormones \& Behavior 2012; 62: 237-242. PMID:22465455 http://dx.doi.org/10. $1016 / j$. yhbeh. 2012.03.007

[50] Li, J., Robinson, M., Malacova, E., Jacoby, P., Foster, J., Eekelen, A. Maternal Life Stress Events in Pregnancy Link to Children's School Achievement at Age 10 Years. J Pediatr. 2013; 162: 4839. PMID:23084705 http://dx.doi.org/10.1016/j.jpeds. 2 012.09 .007

[51] Mattes, E., McCarthy, S., Gong, G., et al. Maternal mood scores in mid-pregnancy are related to aspects of neonatal immune function. Brain, Behavior, \& Immunity. 2009; 23(3): 380388. PMID:19150495 http://dx.doi.org/10.1016/j.bbi.2 008.12 .004

[52] Pankevich, D., Mueller, B., Brockel, B., Bale, T. Prenatal stress programming of offspring feeding behavior and energy balance begins early in pregnancy. Physiology \& Behavior. 2009; 98: 94102. PMID:19394351 http://dx.doi.org/10.1016/j.physb eh. 2009.04.015

[53] Rothenberger, S.E., Resch, F., Doszpod, N., Moehler, E. Prenatal stress and infant affective reactivity at five months of age. Early Human Development. 2011; 87: 129-136. PMID:21194854 http: //dx.doi.org/10.1016/j.earlhumdev.2010.11.014

[54] Taal, H.R., De Jonge, L.L., Tiemeier, H., et al. Parental psychological distress during pregnancy and childhood cardiovascular development. The Generation R Study. Early Human Development. 2013; 89: 547-553. PMID:23391482 http://dx.doi.org/10.1016/j . earlhumdev. 2013.01.005

[55] Rodriguez, A. Pre- and Postnatal Factors in Child Mental Health: the importance of prospective longitudinal studies. European Psychiatry. 2011; 26(1): 2045. http://dx.doi.org/10.1016/S09 24-9338(11) 73748-8

[56] Richetto, J., \& Riva, M. Prenatal maternal factors in the development of cognitive impairments in the offspring. Journal of Reproductive Immunology, In Press, Corrected Proof, Available online 12 April 2014.

[57] Walder, D., Laplante, D., Sousa-Pires, A., Veru, F., Brunet, A., King, S. Prenatal maternal stress predicts autism traits in $61 / 2$ year-old children: Project Ice Storm. Psychiatry Research, in Press, Corrected Proof, Available online 9 May, 2014

[58] Schytt, E., \& Hildingsson, I. Physical and emotional self-rated health among Swedish women and men during pregnancy and the first year of parenthood. Sexual \& Reproductive Healthcare. 2011; 2: 57-64. PMID:21439522 http://dx.doi.org/10.1016/j.s rhc. 2010.12 .003

[59] Ong, S.F., Chan, S., Shorey, S., et al. Postnatal experiences and supports needs of first-time mothers in Singapore: A descriptive qualitative study. Midwifery. 2014; 30: 772-778. PMID:24161493 http://dx.doi.org/10.1016/j.midw.2013.09.004

[60] Santos Jr., H.P.O., Sandelowski, M., Gualda, D.M.R. Bad thoughts: Brazillian women's responses to mothering while experiencing postnatal depression. Midwifery. 2014; 30: 788-794. PMID:24315035 http://dx.doi.org/10.1016/j.midw.2013.11.004
[61] Clarke, K., Saville, N., Shrestha, B., et al. Predictors of psychological distress among postnatal mothers in rural Nepal: A crosssectional community-based study. Journal of Affective Disorders. 2014; 156: 76-86. PMID:24370265 http://dx.doi.org/10.10 $16 / \mathrm{j} \cdot \mathrm{jad} .2013 .11 .018$

[62] Lee, Y.A., Goto, Y. The effects of prenatal and postnatal environmental interaction: Prenatal environmental adaptation hypothesis. Journal of Physiology - Paris. 2013; 107: 483-492. PMID:23624396 http://dx.doi.org/10.1016/j.jphysparis.2013.04.007

[63] Raposa, E., Hammen, G., Brennan, P., Najman, J. The Long-Term Effects of Maternal Depression: Early Childhood Physical Health as a Pathway to Offspring Depression. Journal of Adolescent Health. 2014; 54: 88-93. PMID:24060574 http://dx. doi .org/10.1016 $/ \mathrm{j}$. jadohealth.2013.07.038

[64] Taylor, J., Johnson, M. The role of anxiety and other factors in predicting postnatal fatigue: From birth to 6 months. Midwifery. 2013; 29: 526-534. PMID:23159161 http://dx.doi.org/10.1016/j .midw. 2012.04.011

[65] McVeigh, C. Investigating the relationship between satisfaction with social support and functional status after childbirth. The American Journal of Maternal/Child Health Nursing. 2000; 25: 25-30. http://dx.doi.org/10.1097/00005721-200001000-00006

[66] Parks, P., Lentz, E., Milligan, R., Han, H. What happens when fatigue lingers for 18 months after delivery. Journal of Obstetric gynecologic and Neonatal Nursing. 1999; 28: 87-93. http://dx.doi .org/10.1111/j.1552-6909.1999.tb01969.x

[67] Rychnovsky, J., Beck, C. Screening for postpartum depression in military women with the postpartum depression screening scale. Military Medicine. 2006; 171: 1100-1104.PMID:17153549

[68] Almeida, L., Santos, C., Caldas, J., Ayres-de-Campos, D., Dias, S. Obstetric care in a migrant population with free access to health care. International Journal of Gynaecology \& Obstetrics, In Press, Corrected Proof, Available online 4 May 2014.

[69] Ateah, C. Prenatal Parent Education for First-Time Expectant Parents: "Making it Through Labor is Just the Beginning..." Journal of Pediatric Health Care. 2013; 27(2): 91-97. PMID:23414974 http://dx.doi.org/10.1016/j.pedhc.2011.06.019

[70] Aune, I., Olufsen, V. 'From fragmented to interdisciplinary understanding of integrated antenatal and postnatal care' - An interprofessional project between public health nursing students and midwifery students. Midwifery. 2014; 30: 353-358. PMID:23623472 http://dx.doi.org/10.1016/j.midw.2013.03.007

[71] Charreire, H., \& Combier, E. Poor parental care in an urban area: A geographic analysis. Health \& Place. 2009; 15: 412419. PMID: 18783978 http://dx.doi.org/10.1016/j.healt hplace.2008.07.005

[72] Chhatre, G., Gomez-Lobo, V., Damle, L., Darolia, R. Centering Prenatal Care: Does Group Prenatal Care Improve Adolescent Pregnancy Outcomes? Journal of Pediatric \& Adolescent Gynecology. 2013; 26(2): e47.

[73] Das, V., Agrawai, S., Agarwal, A. Consequences of delay in obstetric care for maternal and perinatal outcomes. International Journal of Gynecology \& Obstetrics. 2010; 109(1): 72-73. http://dx.d oi.org/10.1016/j.ijgo.2009.11.003

[74] Duarte, S.J.H., DeAndrae, S.M.O., Mamede, M.V. Maternal decision on obtaining prenatal care: a study in Brazil. Midwifery. 2011; 27(2): 160-164. PMID:19589630 http://dx.doi.org/10.1016 /j.midw.2009.04.008

[75] Garretto, D., Bernstein, P. CenteringPregnancy: an innovative approach to prenatal care delivery. American Journal of Obstetrics \& Gynaecology. 2014; 210(1): 14-15. PMID:24359868 http://dx.d oi.org/10.1016/j.ajog.2013.10.002

[76] Hale, N., Picklesimer, A., Billings, D., Covington-Kolb. The impact of Centering Pregnancy Group Prenatal Care on postpartum family planning. American Journal of Obstetrics \& Gynecology. 2014; 210(1): 50.e1-e7.

[77] Mogere, D. M., Kaseje, D. Developing a community based referral and counter referral system as a strategy for improving antenatal, postnatal care visits and health facility delivery, case of 
Kisii Country, rural Kenya. Value in Health. 2014; 17(3): A141. http://dx.doi.org/10.1016/j.jval.2014.03.820

[78] Morrow, J., McLachlan, H., Forster, D., Davey, M., Newton, M. Redesigning postnatal care: exploring the views and experiences of midwives. Midwifery. 2013; 29: 159-166. PMID:22342229 http: //dx.doi.org/10.1016/j.midw. 2011.11.006

[79] Novick, G. Women's Experience of Prenatal Care: An Integrative Review. Journal of Midwifery \& Women's Health. 2009; 54(3): 226238. PMID:19410215 http://dx.doi.org/10.1016/j.jmwh. 2009.02 .003

[80] Novick, G., Reid, A., Lewis, J., Kershaw, T., Rising, S. Ickovics, J. Group prenatal care: model fidelity and outcomes. American Journal of Obstetrics \& Gynecology. 2013; 209(2): 112.e1-e6.

[81] Phillippi, J.C. Women's Perceptions of Access to Prenatal Care in the United States: A Literature Review. J Midwifery Womens Health. 2009; 54: 219-225. PMID:19410214 http://dx.doi .org $/ 10.1016 / j$.jmwh. 2009.01.002

[82] Picklesimer, A.H., Billings, D., Hale, N., Blackhurst, D., Covington-Kolb, S. The effect of CenteringPregnancy group prenatal care on preterm birth in a low-income population. Am J Obstet Gynecol. 2012; 206: 415.e1-7.

[83] Seguranyes, G., Costa, D., Fuentelsaz-Gallego, et al. Efficacy of a videoconferencing intervention compared with standard postnatal care at primary care health centres in Catalonia. Midwifery. 2014; 30: 764-771. PMID:24016553 http://dx.doi.org/10.1016/j .midw. 2013.08.004

[84] Wehby, G.L., Murray, J.C., Castilla, E.E., Lopez-Camelo, J.S., Ohsfeldt, R.L. Prenatal care demand and it effects on birth outcomes by birth defect status in Argentina. Economics \& Human Biology. 2009; 7: 84-95. PMID:19059012 http://dx.doi.org/10.1016 $/ j$.ehb.2008.10.001

[85] Werner, E., Goldshore, M., Kajs, B., Badoghaish, W., Henderson, J. A prenatal clinic dedicated to care of obese gravidas. American Journal of Obstetrics \& Gynecology. 2014; 201(1): S267. http://dx.doi.org/10.1016/j.ajog.2013.10.574

[86] Campanella, F., Crescentini, C., Urgesi, C., Fabbro, F. Mindfulnessoriented meditation improves self-related character scales in healthy individuals. Comprehensive Psychiatry. 2014; 55: 1269-1278. PMID:24746260 http://dx.doi.org/10.1016/j.comppsych .2014 .03 .009

[87] Chen, Y., Yang, X., Wang, L., Zhang, X. A randomized controlled trial of the effects of brief mindfulness meditation on anxiety symptoms and systolic blood pressure in Chinese nursing students. Nurse Education Today. 2013; 33: 1166-1172. PMID:23260618 http: //dx.doi.org/10.1016/j.nedt.2012.11.014

[88] Hwang, Y. S., Kearney, P. A systematic review of mindfulness intervention for individuals with development disabilities: Long-term practice and long lasting effects. Research in Developmental Disabilities. 2013; 34 (1): 314-326. PMID:22989576 http://dx.doi .org/10.1016/j.ridd.2012.08.008

[89] Khanna, S., Greeson, J.M. A narrative review of yoga and mindfulness as complementary therapies for addiction. Complementary Therapies in Medicine. 2013; 21(3): 244-252. PMID:23642957 http://dx.doi.org/10.1016/j.ctim.2013.01.008

[90] Klainin-Yobas, Cho, M., Creedy, D. Efficacy of mindfulness-based interventions on depressive symptoms among people with mental disorders: A meta-analysis. International Journal of Nursing Studies. 2012; 49(1): 109-121. PMID:21963234 http://dx.doi.org $/ 10.1016 /$ j.ijnurstu. 2011.08.014

[91] Liehr, P., \& Diaz, N. A Pilot Study Examing the Effect of Mindfulness on Depression and Anxiety for Minority Children. Archives of Psychiatric Nursing. 2010; 24(1): 69-71. PMID:20117691 http: //dx.doi.org/10.1016/j. apnu. 2009.10.001

[92] Marchand, W. Mindfulness Meditation Practices as Adjunctive Treatments for Psychiatric Disorders. Psychiatric Clinics of North America. 2013; 36(1): 141-152. PMID:23538083 http://dx.doi . org $/ 10.1016 / j$.psc. 2013.01 .002

[93] Mirams, L., Poliakoff, E., Brown, R., J. Lloyd, D.M. Brief bodyscan meditation practice improves somatosensory perceptual decision making. Consciousness \& Cognition. 2013; 22(1): 348-
359. PMID:22889642 http://dx.doi.org/10.1016/j.conco g. 2012.07.009

[94] Srivastava, M., Talukdar, U., Lahan, V. Meditation for the management of adjustment disorder anxiety and depression. Complementary Therapies in Clinical Practice. 2011; 17(4): 241245. PMID:21982141 http://dx.doi.org/10.1016/j.ctcp. 2011.04 .007

[95] Alderdice, F., McNeill, J., Lynn, F. A systematic review of systematic reviews of interventions to improve maternal mental health and well-being. Midwifery. 2013; 29: 389-399. PMID:22882967 http: //dx.doi.org/10.1016/j.midw.2012.05.010

[96] Austin, M.-P., Middleton, P., Reilly, N.M., Highet, N.J. Detection and management of mood disorders in the maternity setting: The Australian Clinical Practice Guidelines. Women \& Birth. 2013; 26(1): 2-9. PMID:22217978 http://dx.doi.org/10.1016/j . w ombi.2011.12.001

[97] Byrne, J., Hauck, Y., Fisher, C. Mindfulness Based Childbirth Education. Women \& Birth. 2011; 24(1): S3.

[98] Koszycki, D., Raab, K., Aldosary, F., Bradwejn, J. A multifaith spiritually based intervention for generalized anxiety disorder: a pilot randomized trial. Journal of Clinical Psychology. 2000; 66(4): 430441.

[99] Kristeller, J.L. Meditation and Stress. Encyclopedia of Stress. 2007; 678-685.

[100] Lara, M.A., Navarro, C. Navarrete, L. Outcome results of a psychoeducational intervention in pregnancy to prevent PPD: A randomized control trial. Journal of Affective Disorders. 2010; 122: 109117. PMID:19596446 http://dx.doi.org/10.1016/j.jad.2 009.06 .024

[101] Muzik, M., HMilton, S.E., Rosenblum, K.L., Waxler, E., Hadi, Z. Mindfulness yoga during pregnancy for psychiatrically at-risk women: Preliminary results from a pilot feasibility study. Complementary Therapies in Clinical Practice. 2013; 18(4): 235240. PMID:23059438 http://dx.doi.org/10.1016/j.ctcp. 2012.06.006

[102] Nilaweera, I., Doran, F., Fisher, J. Prevalence, nature and determinants of postpartum mental health problems among women who have migrated from South Asian to high-income countries: A systematic review of the evidence. Journal of Affective Disorders. 2014; 144: 213-226. PMID:25012434 http://dx.doi.org/10.1016 $/ j \cdot j \mathrm{jad} .2014 .05 .021$

[103] Tragea, C., Chrousos, G., Alexopoulos, E., Darviri, C. A randomized controlled trial of the effects of a stress management programme during pregnancy. Complementary Therapies in Medicine. 2014; 22: 203-211. PMID:24731890 http://dx.doi.org/10.10 $16 / j$.ctim. 2014.01.006

[104] Chan, K.P. Spirituality and psychoeducation of pregnant Chinese women in Hong Kong: an evaluation of the effect of an Eastern based meditative intervention on maternal and foetal health status. Doctoral dissertation. 2010; University of Hong Kong: Hong Kong.

[105] McCown, D. Cognitive and Perceptual Benefits of Meditation. Seminars in Integrative medicine. 2004; 2(4): 148-151. http: //dx. doi .org/10.1016/j.sigm.2004.12.001

[106] Berg, A, Hallberg, I.R. Effects of systematic clinical supervision on psychiatric nurses's sense of coherence, creativity, work-related strain, job satisfaction and view of the effects from clinical supervision: a pre-post test design. Journal of Psychiatric and Mental Health Nursing. 1999; 6: 371-81. PMID:10827645 http://dx.doi.org /10.1046/j.1365-2850.1999.00235.x

[107] Delbar, V., Benor, D.E. Impact of a nursing intervention on cancer patients' ability to cope. Journal of Psychosocial Oncology. 2001; 19: 57-75. http://dx.doi.org/10.1300/J077v19n02_04

[108] Forsgarde, M., Westman, B., Nygren, L. Ethical discussion groups as an intervention to improve the climate in interprofessional work with the elderly and disabled. Journal of Interprofessional Care. 2000; 14: 351-361. http://dx.doi.org/10.1080/135618200 20003900

[109] Hillert, L., Savlin, P., Berg, A.L. Environmental illness-effectiveness of a salutogenic group-intervention pro- 
gramme. Scand J Public Health. 2002; 30: 166-75. PMID:12357983 http://dx.doi.org/10.1080/14034940210133852

[110] Chan, D.W. The Chinese ways of coping questionnaire: assessing coping ins econdary school teachers and students in Hong Kong. Psychological Assessment. 1994; 6(2): 108-116. http://dx.doi .org/10.1037/1040-3590.6.2.108

[111] Rosenbaum, M. The role of learned resourcefulness in the selfcontrol of health behavior. In: Rosenbaum, M. (Ed.), Learned Resourcefulness: On Coping Skills, Self-Control and Adaptive Behavior. 1990; 3-30. New York: Springer.

[112] Thompson, B.L., Waltz, J. Everyday mindfulness and minfulness meditation: Overlapping constructs or not? Personality \& Individual Differences. 2007; 43: 1875-1885. http://dx.doi.org/10. $1016 / \mathrm{j}$. paid. 2007.06.017

[113] Youngwanichsetha, S., Phumdoung, S., Ingkathawornwong, T. The effects of mindfulness eating and yoga exercise on blood sugar levels of pregnant women with gestational diabetes mellitus. Applied Nursing Research. 2014. PMID:24629718 http://dx .doi .org/1 $0.1016 / j$.apnr. 2014.02.002

[114] Beitel, M., Genova, M., Schuman-Olivier, Z., et al. Reflections by Inner-City Drug Users on a Buddhist-Based Spirituality-Focused Therapy: A Qualitative Study. American Journal of Orthopsychiatry. 2007; 77(1): 1-9. PMID:17352579 http://dx.doi.org/10. 1037/0002-9432.77.1.1

[115] Yali, A.M., Lobel, M. Coping and distress in pregnancy: an investigation of medically high risk women. J Psychosom Obstet Gynecol. 1999; 20: 39-52. http://dx.doi.org/10.3109/01674829909 075575

[116] Ng, S.M., Yau, J.K.Y., Chan, C.L.W., Ho, D.Y.F. The Measurement of Body-Mind-Spirit Well-Being. Toward Multidimensionality and Transcultural Applicablility. Social Work in Health Care. 2005; 41(1): 33-52. PMID:16048855 http://dx.doi.org/10.1300/J 010v41n01_03

[117] Alderdice, F., Lynn, F. Factor structure of the Prenatal Distress Questionnaire. Midwifery. 2011; 27:553-559. PMID:20832921 ht tp://dx.doi.org/10.1016/j.midw.2010.05.003

[118] Carver, C.S., Scheier, M.F. Situational coping and coping dispositions in a stressful transaction. Journal of Personality and social Psychology. 1994; 66: 184-195. PMID:8126648 http://dx.doi.org /10.1037/0022-3514.66.1.184

[119] Carver, C.S., Scheier, M.F., Weintraub, J.K. Assessing coping strategies: a theorectically based approach. J Pers Soc Psychol. 1989; 56: 267-83. PMID:2926629 http://dx.doi.org/10.1037 /0022-3514.56.2.267

[120] Matthey, S., Henshaw, C., Elliott, S., Barnett, B. Variability in use of cut-off scores and formats on the Edinburgh Postnatal Depression Scale: implications for clinical and research practice. Arch Women Ment Health. 2006; 9: 309-315. PMID:17013761 http: //dx.doi.org/10.1007/s00737-006-0152-x

[121] Pottinger, A.M., Trotman-Edwards, H., Younger, N. Detecting depression during pregnancy and associated lifestyle practices and concerns among women in a hospital-based obstetric clinic in Jamaica. General Hospital Psychiatry. 2009; 31(3): 254-261. PMID:19410104 http://dx.doi.org/10.1016/j.genhospps ych.2009.02.002

[122] Shelton, N.J., Herrick, K.G. Comparison of scoring methods and thresholds of the General Health Questionnaire-12 with the Edinburgh Postnatal Depression Scale in English women. Public Health. 2009; 123: 789-793. PMID:19922968 http://dx.doi.org/10. 1016/j.puhe.2009.09.012

[123] Chan, S., Levy, V. Postnatal depression: a qualitative study of the experiences of a group of Hong Kong Chinese women. Journal of Clinical Nursing. 2004; 13(1): 120-123. PMID:14687304 http://dx.doi.org/10.1046/j.1365-2702.2003.00882 .x

[124] Murray, L., Halligan, S.L., Goodyer, I., Herbert, J. Disturbances in early parenting of depressed mothers and cortisol secretion in offspring: A preliminary study. Journal of Affective Disorders. 2010; 122: 218-223. PMID:19632727 http://dx.doi.org/10.1016 /j.jad.2009.06.034

Published by Sciedu Press
[125] Pluess, M., Bolten, M., Pirke, K-M., Hellhammer, D. Maternal trait anxiety, emotional distress, and salivary cortisol in pregnancy. Biological Psychology. 2010; 83: 169-175. PMID:20026376 http: //dx.doi.org/10.1016/j.biopsycho.2009.12.005

[126] Ananthaswarmy, A. Zen meditation allows greater access to subliminal messages. New Scientist. 2012; 214(2868): 10. http://dx.d oi .org/10.1016/S0262-4079(12)61457-2

[127] Andresen, J. Meditation meets behavioural medicine: The story of experimental research on meditation. In J. Andresen \& R.K.C. Forman (Eds.), Cognitive models and spiritual maps: Interdisciplinary explorations of religious experience (pp. 17-73). Thorverton, UK: Imprint Academic. 2000

[128] Bond, M. The real powers of meditation. The New Scientist. 2011 209: 32-35. http://dx.doi.org/10.1016/S0262-4079(11)6 0048-1

[129] Brown, K., Ryan, R. The benefits of being present: mindfulness and its role in psychological well-being. J Pers Soc Psychol. 2003; 84: 822-48. PMID:12703651 http://dx.doi.org/10.1037/0 $022-3514.84 .4 .822$

[130] Canter, P., Ernst, E. The cumulative effects of Transcendental Meditation on cognitive function: A systematic review of randomized controlled trials. Wiener Klinische Wochenschrift. 2003; 115: 758766. PMID:14743579 http://dx.doi.org/10.1007/BF03040 500

[131] Coghlan, A. Meditation boosts genes that promote good health. New Scientis. 2013; 218: 2916, 12.

[132] Creswell, J., Pacilio, L., Lindsay, E., Brown, K. Brief mindfulness meditation training alters psychological and neuroendocrine responses to social evaluative stress. Psychoneuroendocrinology. 2014; 44:1-12. PMID:24767614 http://dx.doi.org/10.1016 /j.psyneuen.2014.02.007

[133] Fortney, L., Taylor, M. Meditation in Medical Practice: A Review of the Evidence and Practice. Primary Care: Clinics in Office Practice. 2010; 37(1): 81-90. PMID:20188999 http://dx.doi.org/1 $0.1016 / j$.pop. 2009.09.004

[134] Fox, K., Nijeboer, S., Dixon, M., et al. Is meditation associated with altered brain structure? A systematic review and meta-analysis of morphometric neuroimaging in meditation practitioners. Nueroscience \& Biobehavioral Reviews. 2014; 43: 4873. PMID:24705269 http://dx.doi.org/10.1016/j.neubior ev. 2014.03.016

[135] Grant, J.A., Duerden, E.G., Courtemanche, J., et al. Cortical thickness, mental absorption and meditative practice: Possible implications for disorders of attention. Biological Psychology. 2013; 92: 275-281. PMID:23046904 http://dx.doi.org/10.1016/j .biopsycho.2012.09.007

[136] Hasenkamp, W., Wilson-Mendenhall, C.D., Duncan, E., Barsalou, L.W. Mind wandering and attention during focused meditation: A fine-grained temporal analysis of fluctuating cognitive states. Neurolmage. 2012; 59(1): 750-760. PMID:21782031 http://dx.doi .org/10.1016/j .neuroimage.2011.07.008

[137] Jacobs, T., Epel, E., Lin, J.,et al. Intensive meditation training, immune cell telomerase activity and psychological mediators. Psychoneuroendocrinology. 2011; 36(5): 664-611. PMID:21035949 http://dx.doi.org/10.1016/j.psyneuen.2010.09.010

[138] Kasala, E., Bodduluru, L., Maneti, Y., Thipparaboina, R. Effect of meditation on neurophysiological changes in stress mediated depression. Complementary Therapies in Clinical Practice. 2014; 20(1): 74-80. PMID:24439650 http://dx.doi.org/10.1016/j .ctcp. 2013.10.001

[139] Keune, P.M., Bostanov, V., Hautzinger, M. Kotchoubey, B. Approaching dysphoric mood: State-effects of mindfulness meditation on frontal brain asymmetry. Biological Psychology. 2013; 93(1): 105-113. PMID:23410762 http://dx.doi.org/10.1016 /j.biopsycho.2013.01.016

[140] Kozasa, E.H., Sato, J.R., Lacerda, S.S., Barreiros, M.A.M., Radvany, J., Russell, T.A., et al. Meditation training increases brain efficiency in an attention task. Neurolmage. 2012; 59(1): 745749. PMID:21763432 http://dx.doi.org/10.1016/j.neuro image. 2011.06.088 
[141] Lehmann, D., Faber, P.L., Tei, S., et al. Reduced functional connectivity between cortical sources in five meditation traditions detected with lagged coherence using EEG tomography. Neurolmage. 2012; 60(2): 1574-1586. PMID:22266174 http://dx.doi.org/10.10 16/j.neuroimage.2012.01.042

[142] Lu, H., Song, Y., Xu, M., Wang, X., Li, X., Liu, J. The brain structure correlates of individual differences in trait mindfulness: A voxel-based morphometry study. Neuroscience. $2014 ; 272$ : 21 28. PMID:24797333 http://dx.doi.org/10.1016/j.neurosc ience. 2014.04.051

[143] Luders, E., Phillips, O., Clark, K., et al. Bridging the hemispheres in meditation: Thicker callosal regions and enhanced fractional anisotropy (FA) in long-term practitioners. NeuroImage. 2012; 61(1): 181-187. PMID:22374478 http://dx.doi.org/10.1016 /j.neuroimage.2012.02.026

[144] Lutz, A., McFarlin, D.R., Perlman, D.M., Salomons, T.V., Davidson, R.J. Altered anterior insula activation during anticipation and experience of painful stimuli in expert meditatiors. NeuroImage. 2013; 64: 538-546. PMID:23000783 http://dx.doi.org/10. 1016/j.neuroimage. 2012.09.030

[145] Mitrofan, L., Chraif, M., Golu, F., Gatej, E. The Effects of the Unifying Creative-meditation as a Treatment of Self-reported Anxiety in Romanian Amateur Drivers. Procedia-Social \& Behavioral Sciences. 2014; 127: 818-822. http://dx.doi.org/10.1016/j.s bspro.2014.03.361

[146] Pagnoni, G., Cekic, M. Age effects on gray matter volume and attentional performance in Zen Meditation. Neurobiology of Aging. 2008; 28: 1623. PMID:17655980 http://dx.doi.org/10.1016 /j.neurobiolaging.2007.06.008

[147] Saatcioglu, F. Regulation of gene expression by yoga, meditation and related practices: A review of recent studies. Asian Journal of Psychiatry. 2013; 6(1): 74-77. PMID:23380323 http://dx.doi.o rg/10.1016/j.ajp.2012.10.002

[148] Schutte, N., Malouff, J. A meta-analytic review of the effects of mindfulness meditation on telomerase activity. Psychoneuroendocrinology. 2014; 42: 45-48. PMID:24636500 http://dx.doi .org/10.1016/j.psyneuen.2013.12.017

[149] Schwartz, S. Meditation-The Controlled Psychophysical SelfRegulation Process That Works. Explore: The Journal of Science and Healing. 2011; 7(6): 348-353. PMID:22051558 http://dx.d oi.org/10.1016/j.explore.2011.08.007

[150] Shannahoff-Khalsa, D. Meditation: The Science and the Art. Encyclopedia of Human Behavior (2nd ed). 2012; 576-584.

[151] Sperduti, M., Martinelli, P., Piolino, P. A neurocognitive model of meditation based on activation likelihood estimation (ALE) meta-analysis. Consciousness \& Cognition. 2012; 21(1): 269276. PMID:22005087 http://dx.doi.org/10.1016/j.conco g. 2011.09.019

[152] Tan, L., Dienes, Z., Jansari, A., \& Goh, S. Effect of mindfulness meditation on brain-computer interface performance. Consciousness \& Cognition. 2014; 23: 12-21. PMID:24275085 http://dx.doi .org/10.1016/j.concog. 2013.10.010

[153] Tomasino, B., Chiesa, A. Fabbro, F. Disentangling the neural mechansims involved in Hinduism- and Buddhism-related meditations. Brain \& Cognition. 2014; 90: 32-40. PMID:24975229 http: //dx.doi.org/10.1016/j.bandc. 2014.03 .013

[154] Wasi, P. Brain and meditation. 19th World Congress of Neurology, Invited Abstracts/Journal of the Neurolgoical Sciences. 2009; 285(S1): 36.

[155] Wittmann, M. Mindfulness and the Experience of time. ProcediaSocial \& Behavioral Sciences. 2014; 126, 129.

[156] Xue, S., Tang, Y., Tang, R. Posner, M. Short-term meditation induces changes in brain resting EEG theta networks. Brain \& Cognition. 2014; 87:16.

[157] Kim, S., Ki, J. A case study on the effects of the creative art therapy with stretching and walking meditation - Focusing on the improvement of emotional expression and alleviation of somatization symptoms in a neurasthenic adolescent. The Arts in Psychotherapy. 2014; 41(1): 71-78. http://dx.doi.org/10.1016/j.aip. 201 3.11.002
[158] Mackenzie, M., Carlson, L., Paskevich, D., et al. Associations between attention, affect and cardiac activity in a single yoga session for female cancer survivors: An enactive neurophenomenologybased approach. Consciousness and Cognition. 2014; 27: 129146. PMID:24879038 http://dx.doi.org/10.1016/j.conco g. 2014.04.005

[159] Manolea, A. Meditation as Adaptation Strategy. Procedia - Social and Behavioral Sciences. 2014; 127: 631-635. http://dx.doi.o rg/10.1016/j.sbspro.2014.03.325

[160] Alfonso, J.P., Caracuel, A., Delgado-Pastor, L., Verdejo-Garcia, A. Combined goal management training and mindfulness meditation improve executive functions and decision-making performance in abstinent polysubstance abusers. Drug \& Alcohol Dependence. 2011; 117(1): 78-81. PMID:21277705 http://dx.doi.org/10. 1016/j.drugalcdep.2010.12.025

[161] Boettcher, J., Astrom, V., Pahlsson, D., Schenstrom, O., Andersson, G. Carlbring, P. Internet-Based Mindfulness Treatment for Anxiety Disorders: A Randomized Controlled Trial. Behavior Therapy. 2014; 45(2): 241-253. PMID:24491199 http://dx.doi.org/1 $0.1016 / \mathrm{j}$. beth. 2013.11.003

[162] Britton, W., Lepp, N., Niles, H., Rocha, T., Fisher, N., Gold, J. A randomized controlled pilot trial of classroom-based mindfulness meditation compared to an active control condition in sixthgrade children. Journal of School Psychology. 2014; 52(3): 263278. PMID:24930819 http://dx.doi.org/10.1016/j.jsp.2 014.03 .002

[163] Bruce, A., Davies, B. Mindfulness in Hospice Care: Practicing Meditation-in-Action. Qualitative Health Research. 2005; 15(10): 1329-1344. PMID:16263915 http://dx.doi.org/10. $1177 / 1049732305281657$

[164] Carmody, J., Crawford, S., Churchill, L. A pilot study of mindfulness-based stress reduction for hot flashes. Menopause. 2006; 13(5): 1-9. PMID:16932242 http://dx.doi.org/10.10 97/01. gme.0000227402.98933.d0

[165] Carmody, J., Reed. G., Kristeller, J., Merriam, P. Mindfulness, spirituality, and health-related symptoms. Journal of Psychosomatic Research. 2008; 64: 393-403. PMID:18374738 http://dx.doi.org /10.1016/j.jpsychores. 2007.06.015

[166] Chan, K.P. Prenatal meditation influences infant behaviors. Infant Behavior and Development. 2014; 37(4): 556-561. PMID:25063985 http://dx.doi.org/10.1016/j.infbeh.2014.06.011

[167] Enrico, C. The use of meditation techniques in psychotherapy, counseling and psychological training. European Journal of Integrative Medicine. 2010; 4S, 9-123, 80.

[168] Field, T., Diego, M., Delgado, J., Medina, L. Tai chi/yoga reduces prenatal depression anxiety and sleep disturbances. Complementary Therapies in Clinical Practice. 2012; 19: 6-10. PMID:23337557 http://dx.doi.org/10.1016/j.ctcp. 2012.10.001

[169] Foley, E., Baillie, A., Huxter, M., Price, M., Sinclair, E. MinfulnessBased Cognitive Therapy for Individuals Whose Lives Have Been Affected by Cancer: A Randomized Controlled Trial. Journal of Consulting and Clinical Psychology. 2010; 78(1): 72-79. PMID:20099952 http://dx.doi.org/10.1037/a0017566

[170] Friese, M., Messner, C., Schaffner, Y. Mindfulness meditation counteracts self-control depletion. Consciousness \& Cognition, in press, corrected proof, available online 4 Feb 2012.

[171] Hofmann, S.G., Sawyer, A.T., Witt, A.A., Oh, D. The Effect of Mindfulness-Based Therapy on Anxiety and Depression: A MetaAnalytic Review. Journal of Consulting \& Clinical Psychology. 2010; 78(2): 169-183. PMID:20350028 http://dx.doi.org/1 $0.1037 / \mathrm{a} 0018555$

[172] Horrigan, B. Meditation Reduces Pain Scores. The Journal of Science \& Healing. 2010; 7(4): 215-216. http://dx.doi .org/10. 1016/j . explore.2011.04.008

[173] Johnson, D., Penn, D., Fredrickson, B., Kring, A., Meyer, P., Catalino, L., et al. A pilot study of loving-kindness meditation for the negative symptoms of schizophrenia. Schizophrenia Research. 2011; 129(2-3): 137-140. PMID:21385664 http://dx.doi .org/10.10 $16 /$ j.schres. 2011.02 .015 
[174] Katterman, S., Kleinman, B., Hood, M., Nackers, L., Corsica, J. Mindfulness meditation as an intervention for binge eating, emotional eating, and weight loss: A systematic review. Eating Behaviors. 2014; 15(2): 197-204. PMID:24854804 http://dx.doi.org /10.1016/j . eatbeh. 2014.01.005

[175] Khalsa, D. Meditation and Alzheimer's prevention: The forgotten factor. Alzheimer's \& Dementia. 2012; 8(4): 143. http://dx.doi .org/10.1016/j.jalz.2012.05.381

[176] McHugh, L., Simpson, A., Reed, P. Mindfulness as a potential intervention for stimulus over-selectivity in older adults. Research in Developmental Disabilities. 2010; 31: 178-184. PMID:19815376 http://dx.doi.org/10.1016/j.ridd.2009.08.009

[177] Mitrofan, L., Chraif, M., Golu, F., Gatej, E. The Unifying Creativemeditation Technique and Physiological Measurement of Anxiety in Romanian Amateur Drivers. Procedia-Social \& Behavioral Sciences. 2014; 127: 823-827. http://dx.doi.org/10.1016/j.s bspro.2014.03.362

[178] Ostafin, B.D. \& Kassman, K.T. Stepping out of history: Mindfulness improves insight problem solving. Consciousness \& Cognition. 2012; 21: 1031-1036. PMID:22483682 http://dx.doi .org/10. 1016/j.concog.2012.02.014

[179] Reibel, D.K., Greeson, J.M., Brainard, G.C., Rosenzweig, S. Mindfulness-based stress reduction and health-related quality of life in a heterogeneous patient population. General Hospital Psychiatry. 2008; 23: 183-192. http://dx.doi.org/10.1016/S0163-834 3(01) 00149-9

[180] Ruchelli, G., Chapin, H., Darnall, B., Seppala, E., Doty, J., Mackey, S. Compassion meditation training for people living with chronic pain and their significant others: a pilot study and mixed-methods analysis. The Journal of Pain. 2014; 15(4): S117. http://dx.doi .org/10.1016/j.jpain.2014.01.479

[181] Shonin, E., Gordon, W., Slade, K., Griffiths, M. Mindfulness and other Buddhist-derived interventions in correctional settings: A systematic review. Aggression \& Violent Behavior. 2013; 18(3): 365 372. http://dx.doi.org/10.1016/j.avb. 2013.01.002

[182] Simkin, D., Black, N. Meditation and Mindfulness in Clinical practice. Child \& Adolescent Psychiatric Clinics of North America. 2014; 23(3): 487-534. PMID:24975623 http://dx.doi.org/1 $0.1016 / j$.chc. 2014.03 .002

[183] Song, R., Bian, C. Ma, Q. Multifractal analysis of heartbeat dynamics during meditation training. Physica A: Statistical Mechanics \& its Applications. 2013; 392(8): 1858-1862. http://dx.doi.org /10.1016/j.physa.2012.11.050

[184] Troyer, J.A., Tost, J.R., Yoshimura, M., LaFontaine, S., Mabie, A.R Teaching Students How to Meditate Can Improve Level of Consciousness and Problem Solving Ability. Procedia-Social \& Behavioral Sciences. 2012; 69: 153-161. http://dx.doi.org/10.10 16/j.sbspro.2012.11.394

[185] Young, L.A. Mindfulness Meditation: A Primer for Rhematologists. Rheumatic Disease Clinics of North America. 2011; 37(1): 6375. PMID:21220086 http://dx.doi.org/10.1016/j.rdc. 201 0.11 .010

[186] Zeidan, F., Grant, J.A., Brown, C.A., McHaffie, J.G., Coghil, R.C. Mindfulness meditation-related pain relief: Evidence for unique brain mechanisms in the regulation of pain. Neuroscience Letters. 2012; 520(2): 165-173. PMID:22487846 http://dx.doi.org/1 $0.1016 / j$. neulet .2012 .03 .082

[187] Zeller, J. Lamb, K. Mindfulness Meditation to Improve Care Quality and Quality of Life in Long-Term Care Settings. Geriatric Nursing. 2011; 32(2): 114-118. PMID:21239085 http://dx.doi.org /10.1016/j.gerinurse.2010.11.006

[188] Beddoe, A.E., Lee, K.A., Weiss, S.J., Kennedy, H.P., Yang, C.P. The Effects of Mindful Yoga on Sleep in Pregnant Women: A Piliot Study. Biological Research for Nursing. 2010; 11(4): 363370. PMID:20338897 http://dx.doi.org/10.1177/1099800 409356320

[189] Duncan, L.G. \& Bardacke, N. Mindfulness-Based Childbirth and Parenting Education: Promoting Family Mindfulness During the Perinatal Period. J Child Fam Stud. 2010; 19: 190-
202. PMID:20339571 http://dx.doi.org/10.1007/s10826-0 09-9313-7

[190] Robledo-Colonia, A. F., Sandoval-Restrepo, N., MosqueraValderrama, Y., et al. Aeorbic exercise training during pregnancy reduces depressive symptoms in nulliparous women: a randomized trial. Journal of Physiotherapy. 2012; 58(1): 9-15. http://dx.doi . org/10.1016/S1836-9553(12)70067-X

[191] Satyapriya, M., Nagarathna, R., Padmalatha, V., Nagendra, H.R Effect of integrated yoga on anxiety, depression \& well being in normal pregnancy. Complementary Therapies in Clinical Practice. 2013; 198: 230-236. PMID:24199979 http://dx.doi.org/10. 1016/j.ctcp. 2013.06.003

[192] Dunkel, C.S. Psychological science on pregnancy: stress processes, biopsychosocial models, and emerging research issues. Annu Rev Psychol. 2011; 62: 531-58. PMID:21126184 http://dx.doi.org /10.1146/annurev.psych.031809.130727

[193] Bottaccioli, F., Carosella, A., Cardone, R., et al. Brief training of Psychoneuroendocrinoimmunology-based meditation (PNEIMED) reduces Stress Symptom Ratings and improves Control on Salivary Cortisol Secretion under Basal and Stimulated Conditions. EXPLORE: The Journal of Science and Healing. 2014; 10(3): 170179. PMID:24767264 http://dx.doi.org/10.1016/j.explo re.2014.02.002

[194] Carrico, A.W., Ironson, G., Antoni, M.H., et al. A path model of the effects of spirituality on depressive symptoms and 24-h urinaryfree cortisol in HIV-positive persons. Journal of Psychosomatic Research. 2006; 61: 51-58. PMID:16813845 http://dx.doi.org/1 $0.1016 / \mathrm{j} \cdot$ jpsychores.2006.04.005

[195] Gall, T., Charbonneau, C., Clarke, N.H., Joseph, A., Shouldice, L. Understanding the Nature and Role of Spirituality in Relation to Coping and Health: A Conceptual Framework. Canadian Psychology. 2005; 46(2): 88-104. http://dx.doi.org/10.1037/h0087 008

[196] Austin, M.-P., Tully, L., Parker, G. Examining the relationship between antenatal anxiety and postnatal depression. Journal of Affective Disorders. 2007; 101(1-3): 169-174. PMID:17196663 http: //dx.doi.org/10.1016/j.jad.2006.11.015

[197] Dennis, C.L., \& Creedy, D.K. Psychosocial and psychological interventions for treating antenatal depression. Cochrane Database of Systematic Reviews 1. 2009.

[198] Dennis, C.L., \& Hodnet, E.D. Psycholosocial \& psychological interventions for treating postpartum depression. Cochrane Database of Systematic Reviews 1. 2009.

[199] Munoz, R., Le, H.L., Ghosh, C., et al. Prevention of postpartum depression in low-income women: development of the Mamas y Bebes/ Mothers and Babies Course. Cogn. Behav. Pract. 2007; 14(1): 70-83. http://dx.doi.org/10.1016/j.cbpra.2 006.04 .021

[200] Carolan, M., Barry, M., Gamble, M., Turner, K., \& Mascarenas, O. The Limerick Lullaby project: An intervention to relieve prenatal stress. Midwifery. 2012; 28: 173-180. PMID:21371795 http: //dx.doi.org/10.1016/j.midw.2010.12.006

[201] D’Anna-Hernandez, K.L., Ross, R.G., Natvig, C.L., Laudenslager, M.L. Hair cortisol levels as a retrospective marker of hypothalamicpituitary axis activity throughout pregnancy: Comparison to salivary cortisol. Physiology \& Behavior. 2011; 104: 348-353. PMID:21397617 http://dx.doi.org/10.1016/j.physbeh.2 011.02 .041

[202] Kalra, S., Klein, J., Karaskov, T., Woodland, C., Einarson, A., Koren, G. Use of hair cortisol as a biomarker for chronic stress in pregnancy. American Society for Clinical Pharmacology and Therapeutics. 2005; 77(2): 69. http://dx.doi.org/10.1016/j.clpt. 20 04.12 .155

[203] Salacz, P., Csukly, G., Haller, J., Valent. S. Association between subjective feelings of distress, plasma cortisol, anxiety, and depression in pregnant women. European Journal of Obstetrics \& Gynaecology and Reproductive Biology. 2012; 165(2): 225230. PMID:22948130 http://dx.doi.org/10.1016/j.ejogr b. 2012.08 .017 
[204] Urizar Jr., G.G., Milazzo, M., Le, H-N., et al. Impact of stress reduction instructions on stress and cortisol levels during pregnancy. Biological Psychology. 2004; 67: 275-282. PMID:15294386 http: //dx.doi.org/10.1016/j.biopsycho.2003.11.001

[205] Wadhwa, P.D., Dunkel-Schetter, C., Chicz-DeMet, A., Porto, M., Sandman, C.A. Prenatal Psychosocial Factors and the Neuroendocrine Axis in Human Pregnancy. Psychosomatic Medicine. 1996; 58(5): 432-446. PMID:8902895 http://dx.doi.org/10.1097 /00006842-199609000-00006

[206] Weinstock, M. The potential influence of maternal stress hormones on development and mental health of the offspring. Brain, Behavior \& Immunity. 2005; 19: 296-308. PMID:15944068 http: //dx.doi.org/10.1016/j.bbi.2004.09.006

[207] Ventura, T., Gomes, M.C., Carreira, T. Cortisol and anxiety response to a relaxing intervention on pregnant women awaiting amniocentesis. Psychoneuroendocrinology. 2012; 37(1): 148156. PMID:21705148 http://dx.doi.org/10.1016/j.psyne uen. 2011.05.016

[208] Pluess, M., Wurmser, H., Buske-Kirschbaum, A., et al. Positive life events predict salivary cortisol in pregnant women. Psychoneuroendocrinology. 2012; 37: 1336-1340. PMID:22309824 http: //dx.doi.org/10.1016/j.psyneuen.2012.01.006

[209] Newburn, M., \& Bhavnani, V. Left to Your Own Devices: The Postnatal Care Experience of 1260 First-time Mothers (No. 978-09563281-3-7). NCT, London. 2010.

[210] Waldenstrom, U., Rudman, A., Hildingsson, I. Intrapartum and postpartum care in Sweden: women's opinions and risk factors for not being satisfied. Acta Obstetricia et Gynecologica Scandinavica. 2006; 85(5): 551-560. PMID:16752233 http://dx.doi.org/1 $0.1080 / 00016340500345378$

[211] Chuntharapat, S., Petpichetchian, W., Hatthakit, U. Yoga during pregnancy: Effects on maternal comfort, labor pain \& birth outcomes. Complementary Therapies in Clinical Practice. 2008; 14: 105-115. PMID:18396254 http://dx.doi.org/10.1016/j .ctcp. 2007.12 .007

[212] Sun, Y-C., Hung, Y-C, Chang, Y., Kuo, S-C. Effects of a prenatal yoga programme on the discomforts of pregnancy and maternal childbirth self-efficacy in Taiwan. Midwifery. 2010; 26(6): e31e36. PMID:19246136 http://dx.doi.org/10.1016/j.midw. 2009.01 .005

[213] Krans, E., Davis, M., Schwarz, E. Psychosocial risk, prenatal counseling and maternal behavior: findings from PRAMS, 2004-
2008. American Journal of Obstetrics \& Gynecology. 2013; 208(2): 141.e1-e7.

[214] Lane, J., Cole, G. Pregnancy, prenatal care and delivery perceptions and beliefs of resettled African refugee women in the western United States. Contraception. 2013; 88(2): 313. http://dx.doi.org/1 $0.1016 /$ j.contraception. 2013.04.032

[215] Sado, L., Spaho, A., \& Hotchkiss, D.R. The influence of women's empowerment on maternal health care utilization: Evidence from Albania. Social Science \& Medicine. 2014; 114: 169177. PMID:24929918 http://dx.doi.org/10.1016/j.socsc imed.2014.05.047

[216] Berghella, V., Buchanan, E., Pereira, L., \& Baxter, J.K. Preconception care. Obstetrical \& Gynecological Survey. 2010; 65(2): 119132. PMID:20100361 http://dx.doi.org/10.1097/OGX.Ob0 13e3181d0c358

[217] Dutney, A. Religion, infertility and assisted reproductive technology. Best Practice \& Research Clinical Obstetrics \& Gynaecology. 2010; 21(1): 169-180. PMID:17110170 http://dx.doi.org/1 $0.1016 / j$.bpobgyn. 2006.09.007

[218] Haldre, K., Rahu, K., Rahu, M., Karro, H. Individual and familial factors associated with teenage pregnancy: an interview study. European Journal of Public Health. 2009; 19(3): 266270. PMID:19164431 http://dx.doi.org/10.1093/eurpub/ ckn143

[219] Karacam, Z., Onel, K., L\& Gercek, E. Effects of unplanned pregnancy on maternal health in Turkey. Midwifery. 2010; 27(2): 288293. PMID:19773101 http://dx.doi.org/10.1016/j.midw. 2009.07 .006

[220] Timur, S., \& Sahin, N.H. The prevalence of depression symptoms and influencing factors among perimenopausal and postmenopausal women. Menopause. 2010; 17(3): 545-551. PMID:20400922

[221] Van den Broeck, U., D’Hooghe, T., Enzlin, P. Demyttenaere, K. Predictors of psychological distress in patients starting IVF treatment: infertility-specific versus general psychological characteristics. Hum. Reprod. Available online 25 March 2010.

[222] Verhaak, C.M., Linsten, A.M.E., Evers, A.W.M., Braat, D.D.M. Who is at risk of emotional problems and how do you know? Screening of women going for IVF treatment. Human Reproduction. 2010; 25(5): 1234-1240. PMID:20228392 http://dx.doi .o rg/10.1093/humrep/deq054 